\title{
Macera Turistlerinin Duyusal Arayışları ile Aktivite Tercihleri İlişkisi: Türkiye Örneği*
}

\section{The Relation between Sensation Seeking of Adventure Tourists and Activity Preferences: The Case of Turkey}

\author{
Dr. Öğr. Üyesi Serhat BiNGÖL \\ Bilecik Şeyh Edebali Üniversitesi \\ Uygulamalı Bilimler Fakültesi, Bilecik, Türkiye \\ E-posta: serhat.bingol@bilecik.edu.tr
}

\author{
Prof. Dr. Meryem AKOĞLAN KOZAK \\ Anadolu Üniversitesi \\ İşletme Fakültesi, Eskişehir, Türkiye \\ E-posta: mkozak@anadolu.edu.tr
}

Öz

Macera turistleri, macera turizmi deneyiminin bir parçası olarak, davranışları sürekli değişim gösteren ve daha riskli seyahat deneyimleri için sürekli arayış içinde olan turistlerdir. Türkiye'de macera turistlerinin aktivite tercihleri ile duyusal arayışları arasındaki ilişkinin belirlenmesi amacıyla yapılan araştırmada; yamaç paraşütü, tüplü dalış, sörf, rafting, kano, kamp, kayak/snowboard, kaya tırmanışı, trekking ve tur bisikleti aktivitelerine katılan macera turistleri incelenmiştir. Böylelikle, macera aktivitelerine katılan macera turistlerinin duyusal arayışları, uyarılma düzeyleri, rekreasyonel davranış özellikleri ve demografik özelliklerinin ortaya konması amaçlanmıştır. Araşıımada nicel araştırma yöntemi tercih edilmiş olup, veriler anket tekniği ile toplanmıştır. Duyusal arayış ölçeğinden yararlanılarak, kolayda örnekleme yöntemiyle yapılan araştırma, 1246 katılımcı ile gerçekleştirilmiştir. Araştırma sonuçlarına göre, macera turistlerinin duyusal arayışlarının, tercih ettikleri aktiviteler, demografik özellikler ve rekreasyonel davranış özelliklerine göre anlamlı farklılıklar tespit edilmiştir.

Anahtar Kelimeler: Macera turizmi, Macera turisti, Macera aktiviteleri, Duyusal arayış.

\begin{abstract}
Adventure tourists are tourists, whose behaviors are constantly changing as part of the adventure tourism experience and are constantly seeking for more risky travel experiences. The relation between adventure tourist's sensation seeking with their activity preferences which are paragliding, scuba diving, surfing, rafting, canoeing, camping, skiing/snowboarding, rock climbing, trekking and tour bike in Turkey were examined. Thus, sensation seeking, level of arousal, recreational behavior characteristics and demographic characteristics of adventure tourists participating in adventure activities were revealed. Quantitative research method was preferred in the research, and the data were collected by survey technique. 1246 data were obtained from adventure tourists who were selected by convenience sampling method using sensation seeking scale. As a result, it has been revealed that adventure tourists differ in sensation seeking according to their preferred activities, recreational behavior characteristics, and demographic characteristics.
\end{abstract}

Key Words: Adventure tourism, Adventure tourist, Adventure activities, Sensation seeking.

${ }^{*} \mathrm{Bu}$ çalışma "Macera turistlerinin duyusal arayışları ile aktivite tercihleri ilişkisinin Türkiye örneğinde incelenmesi" adlı doktora tezinden üretilmiştir. 


\section{Extensive Summary}

\section{Purpose}

Adventure tourism is a type of tourism which take place in destinations with specific landscapes, cultural exchange, integration with nature and associated with physical activities. On the other hand, adventure tourists are tourists, whose behaviors are constantly changing as part of the adventure tourism experience and are constantly seeking for more risky travel experiences. These tourists are sensation seekers for a sense of accomplishment and continuous improvement and optimal level of arousal, rather than moments of temporary happiness. Therefore, they travel activity-based to participate in high-risk adventure activities. The relation between adventure tourist's sensation seeking with their activity preferences which are paragliding, scuba diving, surfing, rafting, canoeing, camping, skiing/snowboarding, rock climbing, trekking and tour bike in Turkey were examined. Thus, sensation seeking, level of arousal, recreational behavior characteristics and demographic characteristics of adventure tourists participating in adventure activities were revealed.

\section{Background}

Once Aristotle asked, "How should we live?" the simplest answer to the question was "seek for happiness." The pursuit of happiness can be in the form of watching movies, playing games, doing sports, listening to music, or reading books. However, according to Aristotle, this is not real happiness, and a lifestyle that goes on like this does not bring happiness. Eudaimonia, expressed by Aristotle, is a concept that overlaps with development and success rather than happiness. It is not about moments of temporary happiness that come in or how one feels. Therefore, he advocates that people reach true happiness by experiencing the feeling of accomplishment and continuous improvement. For this reason, people need to do activities that will make them feel successful and show certain developments. Hebb and Thompson advocated the idea that organisms behave to achieve an optimal level of arousal and demonstrated that they were taking actions to achieve these effects. Based on this idea, they conclude that people are seeking situations that produce adventure, excitement, and optimal level of arousal. The optimal levels refer to the levels of arousal where people feel best. While Leuba suggests that individuals may differ in terms of arousal for genetic or environmental reasons and these differences may affect their temperament, Berlyne determines the level of arousal; psychological factors such as intensity, fear, risk level, complexity, sudden change, surprise, inconsistency and uncertainty. Fiske and Maddi were interested in sudden changes in the level of arousal just like Berlyne. They also concentrated on reactions in individuals, along with the intensity of the activity, the level of risk, and the mobility it provides. In short, the theory of optimal arousal advocates that when people feel the most appropriate level of arousal, they have the most pleasant moments.

\section{Method}

The studies about sensation seeking and level of arousal of adventure tourists in Turkey is insufficient. Therefore, it would be random to arrange without knowing the important factors or actors about adventure tourists to make decision for management. However, adventure tourism is inherently memorizing and needs plans and policies on this issue should be supported by research. Based on this knowledge gap in the field and the need, the subject of this study is planned to determine the types of activities, 
sensation seeking and level of arousal to allow analysis of adventure tourists. Therefore, quantitative research method was preferred in the research, and the data were collected by survey technique. 1246 data were obtained from adventure tourists who were selected by convenience sampling method between 12 January 2019 ile 6 September 2019 by conducting of sensation seeking scale.

\section{Findings}

Each adventure activities requires different challenges, motivation and sensation seeking as both the way it is done and the degree of difficulty are different. Hence, the sensation of adventure tourists differs according to the type of activity they have chosen. So, the first hypothesis is "H1: Sensation seeking of adventure tourists differ according to their activity types." According to the ANOVA results, sensation seeking of paragliding, rock climbing and rafting participants was higher than those of camping, canoe, surfing, skiing, and scuba diving. In addition, sensation seeking of surf participants was higher than tour bike participants, while sensation seeking of surf and ski participants is higher than canoe participants. Finally, sensation seeking of surfing, skiing and scuba diving participants was higher than that of trekking participants. As a result of the findings reached, first hypothesis $(\mathrm{H} 1)$ of the research was accepted.

Adventure activities offer risky and challenging experiences requires them to be accustomed to high physical skills and intense tempo. Hence, demographic characteristics determine the desire to participate in these activities that require high skill and need to be physically strong. In this context, the second hypothesis of the research is "H2: Sensation seeking of adventure tourists differ according to demographic characteristics." There was significant difference in gender, nationality, educational, occupation and income, however, there was no significant difference in marital status and age in sensation seeking. Therefore, second hypothesis (H2) was partially accepted.

Adventurers behave in participating in physically and mentally challenging activities. They take high levels of risk due to their previous experience. Adventure tourists provide their adrenaline with the risk they take. Adventure tourists need to have high skill levels and participate in adventure activities for a long time to participate in challenging activities. Based on these descriptions the last hypothesis is " $\mathrm{H}$ : Sensation of adventure tourists differ according to their recreational behavior characteristics." ANOVA and T-test result showed that, the last hypothesis (H3) was partially accepted.

\section{Results}

As a result, it has been determined that adventure tourists differ in terms of their sensation seeking, level of arousal and demographic and recreational behavior characteristics within the context of their 10 preferred activities. Adventure tourists with high sensation seeking are expected to make travel arrangements independently, visit unusual or rare preferred destinations, and participate in risky adventure activities. On the other hand, adventure tourists with low sensation seeking are more likely to choose to travel in groups, visit familiar destinations, and participate in less risky adventure activities.

Future studies planned in this context, may focus on the possible emergence or other adventure activities in the different regions of Turkey. In addition, all destinations in Turkey for a specifically chosen adventure activities can be inclusive studies. 
Studies can be conducted on which different adventure activities can be offered for adventure tourists. Creating new experience areas for adventure tourists by offering high-risk activities is a must for destinations. Providing a balance between the adventure tourists and the natural environment and the harmlessness of the environment should be one of the priorities. Since adventure activities are dangerous, there is a risk of injury and death. Destinations can make security arrangements depending on the activities and emergency response areas can be created.

\section{Giriş}

Aristoteles'in "nasıl yaşamalıyız?" sorusuna, en yalın cevabı "mutluluğu arayın" olmuştur. Mutluluk arayışı, film izlemek, oyun oynamak, spor yapmak, müzik dinlemek, kitap okumak veya arkadaşlar ile vakit geçirmek şeklinde olabilir. Ancak Aristoteles'e göre bu gerçek mutluluk değildir ve bu şekilde süren bir yaşam tarzı mutluluk getirmez. Aristoteles tarafından dillendirilen eudaimonia, mutluluktan ziyade gelişme ve başarı ile örtüşen bir kavramdır (Warburton, 2015:25). Gelip geçici mutluluk anları ya da kişinin kendini nasıl hissettiğinden ziyade, başarma duygusu ve sürekli gelişme hissinin gerçek mutluluğa ulaştırabileceğini savunur. Bu nedenle insanlar, kendilerini başarma hissine ulaştıracak ve belirli gelişmeler gösterecekleri aktiviteler yapma ihtiyacı duymaktadırlar.

Macera arayışında olmak, insan doğasının bir gereği olup, dünyada birçok macera aktivitesinin ortaya çıkmasına neden olmaktadır. Macera, kimileri için bir intiyaç, kimileri için ise merak edilen duyusal bir deneyimdir. Macera aktivitelerinde kişiler, tehlikelere meydan okuma duygusuyla optimal düzeyde bir uyarılma elde etmektedirler. Optimal uyarılma duygusu ise kişileri bu duygularını tatmin edici aktivitelere yönelterek, zamanla macera turizmi denilen bir özel ilgi turizminin doğmasına neden olmuştur (Akoğlan Kozak ve Bahçe, 2016:259). Macera turizmi, kişilerin istedikleri macera aktivitelerine katılmalarını sağlayan, çeşitli ekipmanlar yardımıyla yapılan, heyecanlı ve tehlikeli bir turizm türü olarak ifade edilmektedir (Buckley, 2012). Bu kapsamda yer alan çeşitli macera aktivitelerinin ilk örnekleri dağcılığın ön plana çıkmaya başladığı 1940'ı yıllara dayanmaktadır (Hsieh, 2007). Sonrasında, trekking, kaya tırmanışı, tüplü dalış, kamp, rafting ve yamaç paraşütü gibi aktivitelerin önem kazandığı görülmektedir. Macera aktivitelerinin çekiciliği insanlar tarafından zaman içinde fark edilmiş ve bu aktivitelerin yapıldığı alanların her biri ayrı bir turistik alan olmaya başlamıştır (Murray, 2003).

Macera aktiviteleri genellikle riskli olup, hayati tehlikeler içermektedir. Barındırdığı risk unsuru, meydan okumayı gerektirmekte ve ekstrem aktiviteler, macera turistleri için önemli bir dürtü ve motivasyon sağlamaktadır (Swarbrooke vd., 2003). Dünyada turizmin büyüme oranı yüzde dört dolaylarında seyrederken (UNWTO, 2019), macera turizminin büyüme oranı (\%25) çok daha yüksektir (ATTA, 2018). Dolayısıyla, macera turistlerinin sayısı, kitle turistlerine göre küçük ölçekte olmakla birlikte, katılım gruplarının sayısı her geçen yıl hızla artmaktadır. Konu ile ilgili çalışmalar incelendiğinde, (Chen, Ou ve Lin, 2001; Pizam vd., 2004; Sung, 2004; Hsieh, 2007; Buckley, 2012; Ewert vd., 2013; Gilbertson ve Ewert, 2015; Lynch ve Dibben, 2016; Mason vd., 2017) kişilerin doğa ile bütünleşme, yenilik, uyarılma, tehlike ve risk, kaçış, duyusal arayış, kendini gerçekleştirme ve sosyalleşme gibi konularla motive oldukları görülmektedir. Ayrıca, macera turistlerinin motivasyonları ve psikolojik yönleri ile ilgili olarak yapılan çalışmalarda, kişilik kuramları, yüksek düzey deneyim kuramı, akış kuramı, duyusal arayış kuramı ve optimal düzeyde uyarılma kuramından yararlanıldığı görülmektedir (Hebb, 1955; Leuba, 1955; Berlyne, 1960; Fiske ve Maddi, 1961; 
Eysenck 1970; Zuckerman, 1979; Plog 1987; Csikszentmihalyi, 1990; Jackson vd., 2001).

Görüldüğü gibi macera turizmi ve macera turistlerine yönelik farklı kuramlardan yararlanılarak birçok çalışma yapılmıştır. Ancak Türkiye'deki macera turistlerinin aktivite tercihleri, duyusal arayışları ve uyarılma düzeylerini belirlemeye yönelik herhangi bir çalışmanın bulunmaması bir eksiklik olarak görülmektedir. Bu konudaki belirsizlikler ve eksiklikler, macera turizminin Türkiye'de sürdürülebilir olmasında, daha sağlıklı planlanmasında ve pazarlanmasında önemli çıkmazlara sebep olmakta ve rastgele üretilen çözümler getirmektedir. Oysa macera turizmi konusunda dünyada ilk 20 sırada yer alamayan Türkiye'nin (ATTA, 2018), macera turizminin bilimsel dayanaklarla desteklenmesi durumunda, istenilen sıralara yükselmesine katkı sağlayacaktır.

Yamaç paraşütü, kaya tırmanışı, rafting, sörf, tüplü dalış, kayak/snowboard, kano, kamp, trekking ve tur bisikleti gibi macera aktivitelerine katılarak macera yaşamak, kendisine ve yeteneğine meydan okumak üzerine yoğunlaşan kişiler, seyahat etmeyi ve seyahat ettikleri destinasyonlarda farklı aktivitelere katılmayı tercih etmektedirler. Seyahatleri boyunca veya macera aktivitelerine katıldıklarında, yoğun anlar yaşamakta ve düşük düzeyde kaygı duymaktadırlar. Dolayısıyla macera turistleri ve aktivitelerine yönelik önemli faktörleri ya da aktörleri bilmeden bir düzenlemeye gidilmesi, ezberden karar alma ya da rastgele olacaktır. Oysa macera turizmi gibi doğasında ezber bozmak olan bir turizm türünde, bu konudaki plan ve politikaların sağlam araştırmalarla desteklenmesi gerekmektedir. Alandaki bu bilgi boşluğu ve intiyaçtan hareketle araştırma, macera turistlerinin aktivite tercihleri, duyusal arayışları ve uyarılma düzeylerinin belirlenmesi üzerine planlanmıştır. Bu kapsamda araştırmanın amacı, macera turistlerinin duyusal arayışlarının, macera aktiviteleri, rekreasyonel davranış özellikleri ve demografik özelliklerine göre farklılaşma durumunu ortaya koymaktır. Ayrıca, macera turistlerinin katıldıkları aktivite tercihlerine göre demografik özellikler, rekreasyonel davranış özellikleri ve uyarılma düzeyleri arasında karşılaştırmaları yapmaktır. Belirlenen bu amaçlarla birlikte, macera turizmi alanındaki sektör yetkililerine, macera turizminin daha iyi yönetilmesi için gerekli ipuçlarının sağlanması ile macera turizminin sürdürülebilir olması ve sağlıklı gelişmesi için üretilecek politikalara dayanak oluşturmak da çalışmanın diğer alt amaçlarındandır. Böylelikle araştırmanın, aktivite bazlı seyahat eden macera turistlerinin arayışlarına cevap verebilecek planlamaların yapılmasına katkı sağlaması beklenmektedir.

\section{Kuramsal Çerçeve ve Literatür Taraması}

Hebb ve Thompson, organizmaların optimal düzeyde bir uyarılma gerçekleştirmek üzere davrandıkları fikrini savunmuş ve bu etkilere erişmeye yönelik hareketlerde bulunduğunu ortaya koymuşlardır (Apter, 1976). Bu fikirden hareketle Hebb (1955), insanların macera, heyecan ve duyusal uyarılma üreten durumlar aradıkları sonucuna varmıştır. Sonraki yıllarda ise optimal düzeyde uyarılma kuramını, duyusal davranış boyutuna dayandırmıştır. Hebb'in teorisinde, beyin aktiviteleri duyusal uyarılmalardan ayrılarak, duyusal uyarılmanın gerekliliğinin tanınması, "uyarılmanın en uygun düzeyi" etrafında toplanmasına yol açmıştır. Optimal düzeyler, kişilerin kendilerini en iyi hissettikleri uyarılma düzeylerine değinmektedir. Bununla birlikte, uyarılma düzeyi sadece yoğunlukla sınırı olmayıp, yenilik, karmaşıklık, uyuşmazlık ve değişimin de uyarılma düzeyine etkisi bulunmaktadır. Leuba (1955), bireylerin genetik veya çevresel nedenlerden dolayı uyarılma bakımından farklılık gösterebileceğini ve bu farklılıkların mizaçlarını etkileyebileceğini öne sürerken, Berlyne (1960) uyarılma düzeyinin belirleyicilerini; yoğunluk, korku, risk düzeyi, karmaşıklık, değişimin ani oluşu, 
şaşırtıcılık, tutarsızlık ve belirsizlik gibi psikolojik etkenlere bağlamıştır. Fiske ve Maddi (1961) de tıpkı Berlyne gibi uyarılma düzeyindeki ani değişikliklerle ilgilenmişlerdir. Ayrıca, aktivitenin yoğunluğu, risk düzeyi ve sağladığı hareketlilik ile birlikte, bireylerdeki tepkilere yoğunlaşmışlardır. Kısacası, optimal düzeyde uyarılma kuramı, insanların kendilerini uyarılmanın en uygun düzeyinde hissettikleri an, en keyifli anları olduğunu savunmaktadır. Bu duygu durumu, uyarılmanın haz ve korku dengesi düzeyinde olması anlamına gelmektedir. Uygun uyarılma düzeyinin altına düşüldüğünde, organizma çevresinde daha çok uyarılma ararken, organizma optimal düzeyde uyarılmanın üstünde bir uyarılma halinde olduğunda ise daha uygun bir uyarılma düzeyini devam ettirmeye çalışmaktadır (Cüceloğlu, 2018:229-230).

Ewert ve Hollenhorst (1997), macera turistlerinin becerileri arttıkça macera aktivitelerinde pasif katılımcı olmaktan aktif katılımcı olmaya doğru ilerlediklerini belirtmişlerdir. Pizam vd. (2004) ise duyusal arayışta psikolojik özelliklerin, turistik faaliyetlerin seçimi ve önceden belirlenmiş seyahat planlamaları üzerindeki etkilerini araştırmışlardır. İsrail'de yapılan araştırmanın sonuçları, seyahat sırasında ekstrem aktivitelere katılmayı tercih edenlerin, kültürel miras ve doğal cazibe merkezlerini ziyaret edenlere göre duyusal arayış ölçeğinde, daha yüksek puan aldıklarını tespit etmişlerdir. Buckley (2012) macera turistlerinin motivasyonları ile ilgili yapılan 50 çalışmayı incelemiş ve bu çalışmalarda belirtilen motivasyonları, çeşitli terminolojiler kullanarak 14 farklı motivasyon kategorisi altında toplamıştır. Yaş, cinsiyet, aktivite, algılanan zorluklar ve deneyim gibi değişkenlerin incelendiği bu çalışmalar arasında hem uyumluluk hem de zıtlıklar bulunmuştur. Ewert vd., (2013), dört farklı macera aktivitesine katılan 801 kişi ile yaptıkları araştırmada, sosyalleşme, duyusal arayış ve öz imaj olmak üzere üç motivasyon faktörüne ulaşmışlardır. Çalışmada, cinsiyet, aktivite türü ve deneyim düzeyi arasında da anlamlı farklılıklar bulunmuştur.

Lynch ve Dibben (2016), katılımcı motivasyonlarını yorumlayıcı bir metodolojiyi temel alarak araştırmışlardır. Yeni Zelanda'da gerçekleştirilen çalışmada altı farklı macera aktivitesine katılan katılımcılar ile yapılan derinlemesine görüşmeler sonucunda, daha önce macera aktiviteleri için bulunan motivasyon faktörleri ile örtüşen içsel ve dışsal motivasyonlar ortaya konulmuştur. Mason vd., (2017), turist davranışları üzerine yaptıkları çalışmalarında, doğa, risk, beklenti ve sosyalleşme olmak üzere dört faktör elde edilmiş ve turistlerin davranış niyetini etkileyen motivasyon faktörünün doğa faktörü olduğu ortaya çıkmıştır. Gilbertson ve Ewert (2015) ile Park ve Stangl (2020) da benzer şekilde macera turistlerinin daha çok deneyim ve macera arayışı için seyahat ettiklerini belirtmişlerdir. Dolayısıyla, macera ve deneyim yaşamak isteyen macera turistlerinin yüksek risk içeren macera aktivitelerine katılmaları doğal bir sonuçtur. Tayvan'da, Giddy ve Webb (2016)'in Tsitsikamma'da (Güney Afrika), Caber ve Albayrak (2016)'ın Antalya'da yaptıkları araştırma sonuçları da bu araştırmalar ile uyumluluk göstermiştir. Sung (2004) ise macera aktivitelerine katılan turistleri; genel tutkunlar, bütçeye yönelik gençler, kolay aktiviteleri tercih edenler, üst düzey doğa bilimciler, aile tatilcileri ve aktif katılımcılar olmak üzere altı grupta toplamıştır.

Optimal düzeyde uyarılma kuramı, birçok çalışmaya konu olmuş ve çeşitli araştırmaların temelini oluşturmuştur (Hebb, 1955; Berlyne, 1960; Fiske ve Maddi, 1961; Apter, 1976; Zuckerman, 1979). Psikoloji bilimi ile ilgili olan kuramdan başta spor, rekreasyon ve turizm olmak üzere, diğer birçok bilim dalı ve disiplin yararlanmıştır (Zuckerman, 1994; Weber, 2001; Pomfret, 2006). Bu kuramdan yararlanılarak geliştirilen duyusal arayış ölçeği ise başta rekreasyon ve spor olmak üzere birçok alanda kullanılmıştır (Zuckerman, 1983; Pizam vd., 2004; Murray, 2003; Hsieh, 2007; Gilbertson ve Ewert, 2015). Duyusal arayış ölçeği de yıllar içinde araştırmalara konu olmuş ve süreç içinde bir kuram haline gelmiştir. Duyusal arayış ölçeği, bir kişinin 
uyarılma düzeyini ve duyusal arayışlarını ölçmek için geliştirilmiş bileşik bir ölçektir (Zuckerman vd., 1978).

Duyusal arayış ölçeğinde yer alan temel faktörlere ve kuramsal çerçeveye bağlı olarak yapılan değerlendirmeler sonucunda, macera turizminde turist, deneyimin bir parçasıdır ve sürekli bir arayış içindedir. Bu kişiler, turizm endüstrisinin gelişmediği veya kendilerine uzak olan yerleri ziyaret ederek diğer gezginler ile etkileşime girmektedirler. Özellikle, "olağandışı", "egzotik", "otantik" ve "uzak" kavramları ile eşleşen destinasyonların macera turistleri için ön plana çıktığı görülmektedir (Litvin, 2008). Bu destinasyonlar genellikle, turizm işletmelerinin sınırlı olduğu, geleneksel kültürün korunduğu ve nüfus yoğunluğunun az olduğu bölgeleri içermektedir. Geçmişten bugüne Hippiler ve sırt çantalılar olarak adlandırılan maceracılar, bu destinasyonlara seyahat etme eğilimindedirler. Macera turistlerinin katıldıkları macera aktiviteleri, zor ve kolay olarak da sınıflanmaktadır. Hem yapılış şekli hem de zorluk derecesinin farklı olması nedeniyle, her bir aktivite, birbirinden farklı meydan okuma, motivasyon ve duyusal arayış gerektirmektedir. Nihai olarak macera turistlerinin duyusal arayışı, seçtiği aktivite türüne göre farklılaşmaktadır, gerekçesinden hareketle ilk hipotez oluşturulmuştur:

"H1: Macera turistlerinin duyusal arayışları, aktivite çeşitlerine göre istatistiki olarak anlamlı farklılıklar göstermektedir."

Macera aktivitelerinin riskli ve zorlu deneyimler sunması, fiziksel becerileri yüksek ve yoğun tempoya alışık olmalarını gerektirmektedir. Yüksek beceri isteyen ve fiziksel anlamda güçlü olmanın gerektiği bu aktivitelere katılım isteğini, demografik özellikler belirlemektedir. Pizam (2004), Hsieh (2007) ile Gilbertson ve Ewert (2015), farklı kültürlerde yaptıkları çalışmalarda, macera turistlerinin duyusal arayışlarının, yaş, medeni durum, cinsiyet, meslek, eğitim durumu ve gelir durumu gibi demografik özelliklerine göre farklılaştığı sonucuna ulaşmışlardır. Macera turistlerinin karar verme süreçlerinde hem yaşam biçiminin hem de yaş, medeni durum, cinsiyet, meslek, eğitim durumu ve gelir durumu rolünün olduğuna dikkat etmek önemlidir. Fiziksel olarak zorlayıcı macera aktiviteleri ile bağlantılı olarak, insanların fiziksel ve zindelik seviyeleri ve demografik özellikleri, seçtikleri aktivitenin türünü etkilediği veya daha uygun olduğunu gözler önüne sermektedir. Yaş, gelir, eğitim ve medeni durumu başta olmak üzere, macera turistlerinin demografik özellikleri, macera aktiviteleri tercihlerinin yanı sıra duyusal arayışlarını, rekreasyonel davranış özelliklerini ve uyarılma düzeylerini de belirlemektedir. Görüldüğü üzere, macera turistlerinin duyusal arayış için aktivitelere katıımı incelendiğinde, duyusal arayışın demografik özelliklere göre farklılaşması beklenmektedir. Bu bağlamda, araştırmanın ikinci hipotezi:

"H2: Macera turistlerinin duyusal arayışları, demografik özelliklere göre istatistiki olarak anlamlı farklııklar göstermektedir." olarak belirlenmiştir.

Maceraperestlerin fiziksel ve zihinsel açıdan zorlayıcı aktivitelere katılma davranışı göstermesi, çok daha yüksek olasılıklıdır. Daha önceki deneyimlerinin etkisi ile yüksek düzeylerde risk almaktadırlar. Macera turistleri, adrenalinlerini aldıkları risk ile sağlamaktadırlar. Bu bireyler, sahip oldukları deneyim düzeyi ile zorlu aktiviteleri yapıp yapamayacakları riskini göze almaktadırlar. Lipscombe'ye (1999) göre zor aktivitelere katılan macera turistleri, meydan okuma, tehlike ve risk unsurlarını göz önünde bulundurarak başarılı olmak istemektedirler. Macera turistlerinin katılıkları macera aktiviteleri ile birlikte, rekreasyonel davranış özellikleri de farklılaşmaktadır. Macera turistlerinin zorlu aktivitelere katılmak için beceri düzeylerinin yüksek olması ve uzun süredir macera aktivitelerine katılması gerekmektedir. Bireysel olarak taşınan ve 
aktivite seçimin etkileyen bu tür rekreasyon donanım yeterlilikleri ya da rekreasyonel beceri düzeyi ile duyusal arayış arasında bir ilişki olduğu söylenebilir. Örneğin, başlangıç düzeyindeki bir macera turisti ile orta düzey veya profesyonel bir macera turisti arasında aktivite tercihi konusunda farklılık ortaya çıkmaktadır (Hsieh, 2007). Bu açıklamalara dayanarak:

"H3: Macera turistlerinin duyusal arayışları, rekreasyonel davranış özelliklerine göre istatistiki olarak anlamlı farklılıklar göstermektedir." hipotezinin test edilmesine karar verilmiştir.

Bu çalışmada ayrıca, bir hipotez olarak denemesi gerekli görülmeyen, ancak duyusal arayış ölçeğinin, macera turistlerinin duyusal arayışları ile birlikte, uyarılma düzeylerini de ölçen bileşik bir ölçek olup olmadığına yönelik analizler de yapılmıştır. Bu bağlamda, duyusal arayış ölçeğine uygulanan hiyerarşik olmayan kümeleme analizi ile macera turistlerinin uyarılma düzeyleri belirlenmiştir. Böylelikle, Türkiye'de macera turistlerinin hangi düzeylerde uyarılmak için macera aktivitelerine katılım gösterdikleri belirlenmeye çalışılmıştır.

\section{Yöntem}

Yapılan araştırmada, Türkiye'de macera turistlerinin demografik özellikleri, rekreasyonel davranış özellikleri, duyusal arayışları ve uyarılma düzeylerini belirlemek amacıyla betimsel araştırma yaklaşımlarından biri olan tarama araştırmasından faydalanılmıştır. Tarama araştırması, bir grubun belirli özelliklerini ortaya koymak için verilerin toplaması amaçlayan araştırmalardır (Büyüköztürk, 2014:14). Bu kapsamda macera turistlerinin Türkiye'deki macera aktivitelerine katılımlarına yönelik genellemeler yaparak, önerilerde bulunabilmesi amacıyla nicel araştırma yöntemi seçilmiştir. Ayrıca, nicel araştırma yöntemi ile ulaşılan bulguların sayısal olarak değerlendirilmesi ve sonuçların bu yönde nesnel olarak sunulması amaçlanmıştır. Bu kapsamda, araştırmada veri toplama işlemi için anket tekniğinden faydalanılmıştır. Araştırmanın evren ve örneklem seçimi, veri toplama aracı, ölçeklere ilişkin güvenirlik analizleri ve veri analizleri ile ilgili detaylı bilgiler, bu çerçevede açıklanmıştır.

Macera turizminin birçok farklı macera aktivitesini kapsaması ve Türkiye'nin birçok yerinde yapılmasına bağlı olarak araştırmaya, aktivitelerin yapıldığı destinasyonlar ve bu destinasyonlarda ön plana çıkan aktivitelerin belirlenmesi ile başlanmıştır. Kültür ve Turizm Bakanlığı, il kültür ve turizm müdürlükleri, doğa dernekleri, öğrenci kulüpleri, amatör spor kulüpleri, seyahat acenteleri ve ilgili literatürden edinilen bilgiler doğrultusunda, Türkiye'de macera turizmi hareketlerine neden olan 10 macera aktivitesi belirlenmiştir. Yamaç paraşütü, kaya tırmanışı, rafting, sörf, tüplü dalış, kayak/snowboard, kano, kamp, trekking ve tur bisikleti olarak belirlenen macera aktiviteleri, Türkiye'de özellikle turistik macera aktiviteleri olarak en çok tercih edilen aktivitelerdir. Bu bilgilere dayalı olarak yapılan ön çalışma sonucunda araştırmanın evreni, belirlenen 10 macera aktivitesine katılmak amacıyla seyahat eden tüm macera turistleri olarak belirlenmiştir.

Macera aktivitelerinin belirlenmesinin ardından, aktivitelerin hangi destinasyonlarda yapıldığı yine aynı yöntem ile belirlenmiştir. Bütün destinasyonlar listelendikten sonra, macera aktiviteleri ile bütünleşen destinasyonlar seçilmiştir. Saha araştırması, belirlenen 10 macera aktivitesinin ön plana çıktığı destinasyonlarda yapılmıştır. Bu kapsamda araştırma, Fethiye-Ölüdeniz'de yamaç paraşütü, ÇeşmeAlaçatı ve Muğla-Akyaka'da sörf, Kaş'ta tüplü dalış, İzmir-Kaynaklar, AntalyaGeyikbayırı ve Eskişehir-Karakayalar'da kaya tırmanışı, Uludağ, Sarıkamış ve 
Palandöken Kayak Merkezleri'nde kayak/snowboard, Antalya-Olympos-ÇıralıKekova'da kano, Antalya-Köprülü Kanyon ve Çoruh Nehri'nde rafting, İzmir ve Eskişehir'de tur bisikleti, Muğla ve Antalya'da kamp, Fethiye-Likya Yolu'nda trekking aktivitelerine katılan macera turistleri kapsamında yürütülmüştür. Belirlenen destinasyonlardaki aktivitelere katılan macera turistlerinin sayısı ile ilgili net sayıların bilinmemesi nedeniyle, örneklem bu destinasyonlardaki macera aktivitelerine katılan macera turistlerinden, kolayda örnekleme yöntemi ile seçilmiştir. Veriler, 12 Ocak 2019 ile 6 Eylül 2019 tarihleri arasında 1350 macera turistine ulaşılarak, yüz yüze anket tekniği ile toplanmıştır. Elde edilen anketlerden 1246 anket, uygun görülerek, analizlerde kullanılmak üzere numaralandırılmıştır.

Veri toplama aracı olarak Zuckerman vd., (1978) tarafından geliştirilen duyusal arayış ölçeğinden faydalanılmıştır. Duyusal arayış ölçeği, bir bireyin uyarılma düzeyini ve uyarılmak için duyusal arayışlarını ölçmek için geliştirilmiştir. Ölçek, 40 ifadeden oluşmaktadır ve yüksek puanlı ifadeler, duyusal arayışların ve uyarılma düzeyinin yüksek olduğunu gösteren bileşik bir ölçektir. Bu bileşik ölçek, macera arayışı, deneyim arayışı, sıkıntı duyarlılığı ve sınırsızlık olmak üzere, dört faktörden oluşmaktadır. Ölçek ifadeleri için ise aralıklı ölçek türlerinden olan beşli likert ölçeği kullanılmıştır. Bu ölçek ile birlikte, ayrıca rekreasyonel davranış özellikleri ve demografik özelliklere yönelik ifadelerin yer aldığı soru formu oluşturulmuştur.

Duyusal arayış ölçeğinde yer alan ifadeler için gerekli çeviriler yapılıp düzenlendikten sonra uzman görüşü alma yoluna gidilmiştir. Bu uygulama, alanında uzman 13 akademisyen ve turizm sektöründe hizmet veren üç sektör temsilcisi olmak üzere toplam 16 uzman ile 10-30 Nisan 2018 tarihleri arasında gerçekleştirilmiştir. Uzman görüşü alma sürecinde, öncelikle çevirisi yapılmış olan 40 ifadeye sahip orijinal ölçek, uzmanlara sunulmuştur. Daha sonra geri bildirimlere göre düzenlemeler yapılarak ikinci kez aynı uzman grubunun görüşüne sunulmuştur. Bu süreçte, toplam 10 ifade, uzman görüşlerine bağlı olarak ölçekten çıkarılmıştır. Uzmanlardan gelen son görüşlere bağlı olarak ölçekteki ifadeler elden geçirilmiş ve ölçeğin son hali, uzmanlara gönderilmiştir. Yapılan bu düzenlemelerin ardından son halini alan ölçek, içerdiği 30 ifade ile veri toplama işlemine hazır hale gelmiştir. Bu süreç sonunda, soru formuna, macera turistlerinin demografik özellikleri ile ilgili yedi, rekreasyonel davranış özellikleri ile ilgili altı soru eklenmiştir. Bu çerçevede, Bilecik Şeyh Edebali Üniversitesi Etik Kurulu'na başvuru yapılmıştır. İlgili Etik Kurulu'nun 21/10/2020 tarihli ve 11 sayılı toplantısının 11 nolu kararı ile çalışmada etiğe aykırılık bulunmadığına, toplantıya katılanların oy birliği ile karar verilmiştir.

Veri analizi, aritmetik ortalamalar, frekanslar, yüzdeler, standart sapmalar ve Cronbach Alpha değerlerinin hesaplanması için tanımlayıcı istatistiki analizler ile başlamıştır. Macera turistlerinin duyusal arayışlarını ölçmek için ise ölçekte yer alan ifadeler ile açıklayıcı faktör analizi yapılmıştır. Duyusal arayışın aktivite çeşitlerine göre farklılaşma durumlarını incelemek amacıyla bağımsız örneklem $t$ testi ve tekyönlü ANOVA kullanılmıştır. Ayrıca, macera turistlerinin uyarılma düzeylerini ortaya koymak için hiyerarşik olmayan kümeleme analizinden (K-means) yararlanılmıştır. Macera turistlerinin katıldıkları aktivite türlerinin, demografik özellikler, rekreasyonel davranış özellikleri, duyusal arayış ve uyarılma düzeyleri karşılaştırmalarını ortaya koymak için ise çapraz tablolardan yararlanılmıştır.

\section{Bulgular}

Araştırma sonucunda elde edilen bulgular; macera turistlerinin demografik özellikleri ve rekreasyonel davranış özellikleri, faktör analizi, hipotez testleri ve kümeleme analizi 
sonucunda ortaya çıkan, macera turistlerinin uyarılma düzeyleri şeklinde beş başlık altında toplanmıştır. Bu başlıklar itibariyle elde edilen bulgulara aşağıda yer verilmektedir.

\subsection{Macera Turistlerinin Demografik Özellikleri}

Araştırmaya katılan macera turistlerinin demografik özellikleri değerlendirildiğinde, macera turistlerinin büyük çoğunluğunun yerli turistlerden oluştuğu görülmektedir $(\% 78,2)$. Yerli ve yabancılardan oluşan macera turistlerinin cinsiyetleri incelendiğinde, erkeklerin oranı yüzde 60,4 , kadınların oranı ise yüzde 39,6 olarak saptanmıştır. Macera turistlerinin büyük bölümünün yaşları $25-40$ aralığındadır $(\% 67,6)$. Ayrıca, macera turistlerinin büyük çoğunluğunun bekâr $(\% 78,3)$, yarısından fazlasının $(\% 58,3)$ ise lisans mezunu olduğu görülmüştür. Son olarak, macera turistlerinin meslekleri ve gelirleri incelendiğinde, bu turistlerinin çoğunlukla özel sektör $(\% 37,9)$ ve kamu sektöründe $(\% 27,8)$ çalıştıkları, gelirlerinin ise 4000 TL'nin üzerinde $(\% 56,2)$ olduğu ortaya çıkmıştır (Tablo 1).

Tablo 1: Macera turistlerinin demografik özellikleri

\begin{tabular}{|lccc|}
\hline Demografik Özellikler & Gruplar & Sayı & Yüzde \\
Cinsiyet & Kadın & 493 & 39,6 \\
& Erkek & 753 & 60,4 \\
& $16-24$ & 263 & 21,1 \\
Yaş & $25-30$ & 510 & 40,9 \\
& $31-40$ & 333 & 26,7 \\
Milliyet & $41-55$ & 122 & 9,8 \\
& 56 ve üstü & 18 & 1,4 \\
Medeni Durum & Yerli & 975 & 78,2 \\
& Yabancı & 271 & 21,8 \\
& Bekâr & 975 & 78,3 \\
& Evli & 271 & 21,7 \\
Meslek & Öğrenci & 196 & 15,7 \\
& Kamu & 346 & 27,8 \\
& Özel sektör & 472 & 37,9 \\
& İşçi & 69 & 5,5 \\
& İssiz & 71 & 5,7 \\
& Sporcu & 80 & 6,4 \\
Eğitim Durumu & Emekli & 12 & 1,0 \\
& İlköğretim & 23 & 1,8 \\
& Lise & 123 & 9,9 \\
Gelir & Ön Lisans & 189 & 15,2 \\
& Lisans & 727 & 58,3 \\
& Lisansüstü & 184 & 14,8 \\
& 2000 ve altı & 195 & 15,7 \\
& $2001-4000$ & 313 & 25,1 \\
& $4001-6000$ & 378 & 30,3 \\
& 6001 ve üstü & 360 & 25,9 \\
\hline
\end{tabular}

Araştırma kapsamında belirlenen 10 macera aktivitesinin tamamında yerli turist sayısı, yabancı turist sayısından daha fazladır (Tablo 2). Yerli ve yabancı turist sayısı arasındaki en büyük fark ise kamp aktivitesinde ortaya çıkmıştır (yerli sayısı=120, yabancı sayısı=10). Erkekler macera aktivitelerinin tamamına, kadınlardan daha çok katılım göstermişlerdir. Macera aktivitelerine katılımda cinsiyet arasındaki en büyük fark ise yamaç paraşütünde belirlenmiştir (erkek sayısı=92, kadın sayısı=32). Macera turistlerinin katıldıkları aktivite türleri ile yaşları karşılaştırıldığında, kamp, kaya tırmanışı, sörf, rafting ve tüplü dalış aktivitelerine katılanların büyük çoğunluğunun yaşlarının 16-30 arasında değiştiği görülmüştür. Diğer beş aktivite olan tur bisikleti, kano, yamaç paraşütü, kayak/snowboard ve trekking aktivitelerinde ise katılımcıların 
yaşları, ağırlıklı olarak 31-40 arasındadır. Medeni durum tüm aktivitelerde benzerlik göstermiş ve katılımcıların büyük çoğunluğunun bekâr olduğu ortaya çıkmıştır.

Tablo 2: Macera aktivite türlerine göre demografik özelliklerin karşılaştırılması

\begin{tabular}{|c|c|c|c|c|c|c|}
\hline $\begin{array}{l}\text { Demografik } \\
\text { Özellikler }\end{array}$ & Gruplar & $\begin{array}{l}\text { Bisiklet } \\
(S=129)\end{array}$ & $\begin{array}{c}\text { Kamp } \\
(S=130)\end{array}$ & $\begin{array}{c}\text { Kano } \\
(S=112)\end{array}$ & $\begin{array}{l}\text { Y.Paraşütü } \\
(S=124)\end{array}$ & $\begin{array}{l}\text { K.Tırmanışı } \\
(S=117)\end{array}$ \\
\hline \multirow{2}{*}{ Cinsiyet } & Kadın & 53 & 64 & 49 & 32 & 52 \\
\hline & Erkek & 76 & 66 & 63 & 92 & 65 \\
\hline \multirow{4}{*}{ Yaş } & $16-24$ & 4 & 47 & 26 & 10 & 37 \\
\hline & $25-30$ & 44 & 64 & 47 & 36 & 71 \\
\hline & $31-40$ & 50 & 18 & 31 & 56 & 9 \\
\hline & 41-üst & 31 & 1 & 8 & 22 & 0 \\
\hline \multirow{2}{*}{ Milliyet } & Yerli & 99 & 120 & 83 & 85 & 94 \\
\hline & Yabancı & 30 & 10 & 29 & 39 & 23 \\
\hline \multirow{2}{*}{ M. Durum } & Bekâr & 95 & 103 & 89 & 100 & 112 \\
\hline & Evli & 34 & 27 & 23 & 24 & 5 \\
\hline \multirow{4}{*}{ Meslek } & Öğrenci & 4 & 33 & 39 & 8 & 31 \\
\hline & Kamu & 51 & 55 & 29 & 4 & 27 \\
\hline & Özel S. & 63 & 31 & 26 & 64 & 41 \\
\hline & İşçi & 4 & 1 & 12 & 20 & 3 \\
\hline \multirow[b]{5}{*}{ Eğitim Durumu } & Sporcu & 0 & 4 & 6 & 20 & 0 \\
\hline & Çalışmıyor & 7 & 1 & 10 & 8 & 15 \\
\hline & İlköğretim & 0 & 3 & 7 & 0 & 0 \\
\hline & Lise & 7 & 22 & 39 & 9 & 9 \\
\hline & Ön Lisans & 15 & 13 & 22 & 19 & 28 \\
\hline & Lisans & 71 & 75 & 34 & 68 & 75 \\
\hline & Lisansüstü & 36 & 17 & 10 & 28 & 5 \\
\hline & 2000-alt & 6 & 39 & 24 & 0 & 32 \\
\hline \multirow{3}{*}{ Gelir } & $2001-4000$ & 48 & 46 & 28 & 18 & 28 \\
\hline & $4001-6000$ & 51 & 28 & 23 & 34 & 17 \\
\hline & 6001-üst & 24 & 17 & 37 & 72 & 17 \\
\hline $\begin{array}{l}\text { Demografik } \\
\text { Özellikler }\end{array}$ & Gruplar & $\begin{array}{c}\text { Sörf } \\
(S=125)\end{array}$ & $\begin{array}{c}\text { Kayak } \\
(\mathrm{S}=129)\end{array}$ & $\begin{array}{l}\text { Rafting } \\
(\mathrm{S}=108)\end{array}$ & $\begin{array}{c}\text { Trekking } \\
(\mathrm{S}=156)\end{array}$ & $\begin{array}{c}\text { T.Dalış } \\
(S=116)\end{array}$ \\
\hline \multirow{3}{*}{ Cinsiyet } & Kadın & 45 & 38 & 42 & 70 & 48 \\
\hline & Erkek & 80 & 91 & 66 & 86 & 68 \\
\hline & $16-24$ & 43 & 23 & 30 & 6 & 37 \\
\hline \multirow{3}{*}{ Yaş } & $25-30$ & 31 & 64 & 44 & 56 & 53 \\
\hline & $31-40$ & 36 & 34 & 26 & 54 & 19 \\
\hline & 41 ve üstü & 15 & 8 & 8 & 40 & 7 \\
\hline \multirow{2}{*}{ Milliyet } & Yerli & 96 & 97 & 77 & 134 & 89 \\
\hline & Yabancı & 29 & 32 & 31 & 22 & 27 \\
\hline \multirow{4}{*}{ M. Durum } & Bekâr & 100 & 73 & 90 & 120 & 93 \\
\hline & Evli & 25 & 56 & 18 & 36 & 23 \\
\hline & Öğrenci & 29 & 13 & 24 & 5 & 20 \\
\hline & Kamu & 10 & 49 & 18 & 69 & 34 \\
\hline \multirow{6}{*}{ Meslek } & Özel sektör & 51 & 41 & 42 & 72 & 41 \\
\hline & İşçi & 6 & 11 & 5 & 4 & 3 \\
\hline & Sporcu & 25 & 7 & 9 & 0 & 9 \\
\hline & Çalışmıyor & 4 & 8 & 10 & 6 & 9 \\
\hline & illköğretim & 6 & 3 & 2 & 0 & 2 \\
\hline & Lise & 8 & 11 & 2 & 9 & 7 \\
\hline \multirow[t]{4}{*}{ Eğitim Durumu } & Ön Lisans & 20 & 3 & 24 & 20 & 25 \\
\hline & Lisans & 82 & 96 & 71 & 85 & 70 \\
\hline & Lisansüstü & 9 & 16 & 9 & 42 & 12 \\
\hline & 2000-alt & 20 & 15 & 22 & 10 & 27 \\
\hline \multirow{3}{*}{ Gelir } & $2001-4000$ & 23 & 22 & 17 & 61 & 25 \\
\hline & $4001-6000$ & 24 & 48 & 32 & 62 & 33 \\
\hline & 6001 -üst & 58 & 44 & 37 & 23 & 31 \\
\hline
\end{tabular}

Macera turistlerinin katılıkları macera aktiviteleri ile eğitim, meslek ve gelir durumlarına bakıldığında, kano aktivitesinde lise mezunu sayısı daha fazla iken, diğer tüm aktivitelerde lisans mezunlarının sayısı daha fazladır. Kamp ve kayak aktivitelerine 
katılanların çoğunluğu kamu sektöründe, trekking aktivitesine katılanların çoğunluğu ise kamu sektöründe veya özel sektörde çalışmaktadırlar. Kano aktivitesine katılanların çoğunluğu öğrenci iken, kalan diğer aktivitelere katılanların çoğunluğu ise özel sektörde çalışmaktadır. Son olarak, katılımcıların gelir durumları ile ilgili elde edilen veriler, kaya tırmanışı ve kamp aktivitelerine katılanların 0-4000 TL aralığında gelire sahip olduğunu göstermektedir. Trekking ve tur bisikleti aktivitelerine katılanların gelirleri 2001-6000 TL aralığında, kayak ve tüplü dalış katılımcılarının gelirleri 4000 TL'nin üzerinde, sörf, rafting, kano ve yamaç paraşütü katılımcılarının gelirlerinin ise 6000 TL'nin üzerinde olduğu ortaya çıkmıştır.

\subsection{Macera Turistlerinin Rekreasyonel Davranış Özellikleri}

Macera turistlerinin rekreasyonel davranış özelliklerine yönelik yapılan analizler ile macera turistlerinin aktivite süresi değerlendirildiğinde, macera turistlerinin büyük bir bölümünün 1-7 yıllık $(\% 58,1)$ bir süredir bu aktivitelere katılım gösterdikleri ortaya çıkmıştır (Tablo 3). Macera turistlerinin çoğunluğu kendilerini amatör $(\% 44,9)$ olarak tanımlarken, aktiviteler için yıllık ortalama harcamaları ise $0-1000 \mathrm{TL}(\% 37,3)$, olarak ortaya çıkmıştır. Macera turistleri aktivitelere genellikle yılda 2-5 defa $(\% 33,9)$ katılım göstermiş ve aktivelere her defasında ortalama 2-7 (\%63) saat arasında zaman harcamışlardır. Ayrıca, macera turistlerinin yüzde 94,4'ü katıldıkları aktivitelere tekrar katılmak istediklerini belirtmişlerdir.

Tablo 3: Macera turistlerinin rekreasyonel davranış özellikleri

\begin{tabular}{|lccc|}
\hline Rekreasyonel & Gruplar & Sayı & Yüzde \\
Davranış Özellikleri & 1 yıldan az & 170 & 13,6 \\
& $1-3$ yıl & 378 & 30,3 \\
Aktivite Süresi & $4-7$ yıl & 341 & 27,8 \\
& $8-10$ yıl & 213 & 17,1 \\
& 11 yıl ve üstü & 144 & 11,6 \\
& Başlangıç & 156 & 12,5 \\
Beceri Düzeyi & Amatör & 559 & 44,9 \\
& Orta düzey & 376 & 30,2 \\
& Profesyonel/Eğitimci & 155 & 12,4 \\
& 1000 ve altı & 465 & 37,3 \\
Yıllık Harcama & $1001-2000$ & 281 & 22,6 \\
& $2001-5000$ & 247 & 19,8 \\
& 5001 ve üstü & 253 & 20,3 \\
& Yılda 1 & 131 & 10,5 \\
Katılım Sıklı̆gı & Yılda 2-5 & 422 & 33,9 \\
& Yılda 6-11 & 190 & 15,2 \\
& Ayda 1 & 262 & 21,0 \\
& Ayda 2 ve üstü & 241 & 19,3 \\
& 2 saatten az & 96 & 7,7 \\
\multirow{3}{*}{ Zaman Harcama } & $2-4$ & 460 & 36,9 \\
& $4-7$ & 325 & 26,1 \\
& $8-10$ & 147 & 11,8 \\
& 11 ve üstü & 218 & 17,5 \\
Tekrar Katılım & Evet & 1176 & 94,4 \\
& Hayır & 70 & 5,6 \\
\hline
\end{tabular}

Macera turistlerinin rekreasyonel davranış özellikleri ile macera aktivite türlerinin karşılaştırılmasına yönelik bulgulara Tablo 4'te yer verilmiştir. Tablo incelendiğinde, kano aktivitesine katılanların çoğunluğu bir yıldan daha az bir süredir bu aktiviteye 
katıldıklarını belirtmişlerdir. Kamp, kaya tırmanışı, kayak, rafting ve tüplü dalış yapanların çoğunluğu için aktivitelere katılım süresi 1-3 yıl olurken, bisiklet, yamaç paraşütü, sörf ve trekking aktivitesine katılanların çoğunluğu için ise aktivitelere katılım süresi 4-7 yıl olmuştur. Macera turistlerinin beceri düzeyleri incelendiğinde, kano, sörf ve tüplü dalış yapan katılımcıların çoğunluğu, kendilerini orta düzey öğrenci olarak tanımlarken, geriye kalan yedi aktivitenin tümünde katılımcıların çoğunluğu, kendilerini amatör olarak tanımlamışlardır.

Macera turistlerinin aktiviteler için yıllık ortalama harcamaları incelendiğinde, kamp, kano, kaya tırmanışı, rafting ve tüplü dalış aktivitelerine katılanların çoğunluğunun, ortalama 1000 TL'nin altında harcama yaptıkları görülmüştür. Ayrıca, bisiklet, yamaç paraşütü ve trekking aktivitelerine katılanların çoğunluğunun 1001-2000 TL, sörf ve kayak aktivitelerine katılanların çoğunluğunun ise 5000 TL üzerinde harcama yaptıkları saptanmıştır. Macera turistleri aktivitelere katılım sıklıkları bakımından değerlendirildiğinde, kamp, kano, kaya tırmanışı, yamaç paraşütü ve tüplü dalış aktivitelerine katılanların çoğunluğu, yılda 2-5 defa aktivitelere katılım göstermişlerdir. Bisiklet, rafting ve trekking aktivitelerine katılanların çoğunluğu aktivitelere ayda bir defa katılırken, sörf ve kayak aktivitelerine katılanların çoğunluğu ise bu aktivitelere ayda iki veya daha fazla katılım göstermişlerdir. Son olarak, bisiklet, kamp ve trekking aktivitelerine katılanların çoğunluğu, aktivitelere her defasında ortalama 4-7 saat arası zaman harcarken, diğer yedi macera aktivitesini katılanların çoğunluğu ise aktivitelere ortalama 2-4 saat zaman harcamışlardır. Belirlenen 10 aktivitenin tümünde, macera turistlerinin büyük çoğunluğu aktivitelere tekrar katılmak istediklerini belirtmişlerdir.

Tablo 4: Macera aktivite türlerine göre rekreasyonel davranış özelliklerinin karşılaştırılması

\begin{tabular}{|c|c|c|c|c|c|c|}
\hline $\begin{array}{l}\text { Rekreasyonel } \\
\text { D. Özellikleri }\end{array}$ & Gruplar & $\begin{array}{l}\text { Bisiklet } \\
(\mathrm{S}=129)\end{array}$ & $\begin{array}{c}\text { Kamp } \\
(S=130)\end{array}$ & $\begin{array}{c}\text { Kano } \\
(S=112)\end{array}$ & $\begin{array}{l}\text { Y.Paraşütü } \\
(S=124)\end{array}$ & $\begin{array}{c}\text { K.Tırmanışı } \\
(S=117)\end{array}$ \\
\hline & 1 yıldan az & 10 & 30 & 41 & 13 & 10 \\
\hline & $1-3$ yıl & 24 & 45 & 37 & 28 & 56 \\
\hline \multirow[t]{4}{*}{ Aktivite Süresi } & 4-7 yıl & 38 & 32 & 24 & 53 & 26 \\
\hline & $8-10$ yıl & 34 & 13 & 6 & 14 & 15 \\
\hline & 11 yıl ve üstü & 23 & 10 & 4 & 16 & 10 \\
\hline & Başlangıç & 6 & 28 & 27 & 36 & 10 \\
\hline \multirow{4}{*}{ Beceri Düzeyi } & Amatör & 75 & 49 & 33 & 50 & 67 \\
\hline & Orta düzey & 33 & 43 & 41 & 26 & 30 \\
\hline & Profesyonel & 15 & 10 & 11 & 12 & 10 \\
\hline & 1000 ve altı & 29 & 85 & 74 & 20 & 55 \\
\hline \multirow{5}{*}{ Yıllık Harcama } & $1001-2000$ & 40 & 18 & 18 & 52 & 27 \\
\hline & 2001-5000 & 28 & 15 & 17 & 38 & 20 \\
\hline & 5001 ve üstü & 32 & 12 & 3 & 14 & 15 \\
\hline & YIlda 1 & 4 & 33 & 36 & 20 & 6 \\
\hline & Yılda 2-5 & 32 & 65 & 42 & 52 & 46 \\
\hline \multirow[t]{4}{*}{ Katılım Sıklığı } & Yılda 6-11 & 23 & 16 & 12 & 28 & 15 \\
\hline & Ayda 1 & 39 & 14 & 6 & 12 & 40 \\
\hline & Ayda 2 ve üstü & 31 & 2 & 16 & 12 & 10 \\
\hline & 2 saatten az & 1 & 11 & 4 & 54 & 5 \\
\hline \multirow{4}{*}{$\begin{array}{l}\text { Zaman } \\
\text { Harcama }\end{array}$} & $2-4$ & 28 & 35 & 34 & 46 & 71 \\
\hline & $5-7$ & 46 & 36 & 30 & 12 & 15 \\
\hline & $8-10$ & 21 & 6 & 24 & 0 & 16 \\
\hline & 11 ve üstü & 33 & 42 & 20 & 12 & 10 \\
\hline \multirow{2}{*}{ Tekrar Katılım } & Evet & 121 & 118 & 104 & 117 & 121 \\
\hline & Hayır & 8 & 12 & 8 & 0 & 4 \\
\hline
\end{tabular}


Tablo 4'ün Devamı

\begin{tabular}{|c|c|c|c|c|c|c|}
\hline \multirow[t]{3}{*}{$\begin{array}{l}\text { Rekreasyonel } \\
\text { D. Özellikleri }\end{array}$} & Gruplar & $\begin{array}{l}\text { Sörf } \\
(S=125)\end{array}$ & $\begin{array}{l}\text { Kayak } \\
(S=129)\end{array}$ & $\begin{array}{l}\text { Rafting } \\
(S=108)\end{array}$ & $\begin{array}{l}\text { Trekking } \\
(S=156)\end{array}$ & $\begin{array}{l}\text { T.Dalış } \\
(S=116)\end{array}$ \\
\hline & 1 yıl ve daha az & 16 & 16 & 9 & 12 & 13 \\
\hline & $1-3$ yıl & 31 & 46 & 33 & 36 & 42 \\
\hline \multirow[t]{4}{*}{ Aktivite Süresi } & 4-7 yıl & 32 & 31 & 28 & 45 & 32 \\
\hline & $8-10 \mathrm{yıl}$ & 23 & 28 & 23 & 41 & 16 \\
\hline & 11 yıl ve üstü & 23 & 8 & 15 & 22 & 13 \\
\hline & Başlangıç & 8 & 16 & 7 & 4 & 14 \\
\hline \multirow{4}{*}{ Beceri Düzeyi } & Amatör & 31 & 74 & 48 & 92 & 40 \\
\hline & Orta düzey & 53 & 29 & 36 & 40 & 45 \\
\hline & Profesyonel & 33 & 10 & 17 & 20 & 17 \\
\hline & 1000 ve altı & 42 & 41 & 36 & 32 & 51 \\
\hline \multirow{5}{*}{ Yıllık Harcama } & $1001-2000$ & 14 & 20 & 19 & 55 & 18 \\
\hline & $2001-5000$ & 27 & 26 & 24 & 31 & 21 \\
\hline & 5001 ve üstü & 44 & 42 & 29 & 38 & 26 \\
\hline & YIlda 1 & 2 & 16 & 3 & 4 & 7 \\
\hline & Yılda 2-5 & 37 & 30 & 31 & 33 & 53 \\
\hline \multirow[t]{4}{*}{ Katılım Sıklığı } & YIlda 6-11 & 15 & 26 & 14 & 28 & 13 \\
\hline & Ayda 1 & 22 & 26 & 33 & 52 & 19 \\
\hline & Ayda 2 ve üstü & 49 & 31 & 27 & 39 & 24 \\
\hline & 2 saatten az & 3 & 11 & 3 & 0 & 4 \\
\hline \multirow{4}{*}{$\begin{array}{l}\text { Zaman } \\
\text { Harcama }\end{array}$} & $2-4$ & 61 & 55 & 51 & 30 & 49 \\
\hline & $4-7$ & 36 & 34 & 25 & 61 & 30 \\
\hline & $8-10$ & 13 & 19 & 19 & 20 & 9 \\
\hline & 11 ve üstü & 12 & 10 & 10 & 45 & 24 \\
\hline \multirow{2}{*}{ Tekrar Katılım } & Evet & 121 & 125 & 106 & 143 & 109 \\
\hline & Havir & 4 & 4 & 2 & 13 & 7 \\
\hline
\end{tabular}

\subsection{Faktör Analizi}

Duyusal arayış ölçeği kapsamında ortaya çıkan faktörlerinin belirlenmesi amacıyla araştırmanın bu aşamasında, açıklayıcı faktör analizinden yararlanılmıştır. Açıklayıcı faktör analizi, yapıların temelini oluşturan göstergelerin ilişkileri hakkında yeterli ve detaylı bir bilginin bulunmadığı durumlarda başlangıç analizi olarak kullanılmaktadır (Creswell, 2013). Açıklayıcı faktör analizinin bir araştırmada kullanılabilmesi için çeşitli varsayımların test edilmesi gerekmektedir (Hair vd., 2005). Bu bağlamda ifadeler arasındaki korelasyonlar incelenmiş, örneklem yeterliliğini test etmek için, Kaiser Meyer Olkin Testi ve değişkenler arasındaki ilişkiyi gösteren Bartlett's Küresellik Testi gerçekleştirilmiştir. KMO değeri 0,778 , Bartlett's Küresellik Testi sonucu ise $X^{2}=$ $6417,041, p=0,00$ olarak ortaya çıkmıştır. KMO değerlerinin 0,50 'den büyük olması, örneklemin faktör analizi için yeterli olduğunu gösterdiğinden (Creswell, 2013; Hair vd., 2005), bu veriler üzerinden faktör analizi yapılabileceği sonucuna varılmıştır. Böylece elde edilen verilerin anlamlı farklılık gösterdiği ve faktör analizi yapmaya uygun olduğu saptanmıştır.

Ölçekte yer alan 30 ifade ile gerçekleştirilen açıklayıcı faktör analizi sonucunda, faktör yük değerleri ve ortak varyans değerleri yüksek olan 24 ifadenin oluşturduğu dört faktörlü bir yapı elde edilmiştir. Faktör analizi sonucunda kalan diğer altı ifade ise faktör yük değerlerinin 0,40 'ın altında olması veya birden fazla faktörde yer alması nedeniyle faktör analizinden çıkarılmıştır. Ayrıca, araştırma kapsamında ortaya çıkan dört faktöre ilişkin güvenirlilik analizleri de yapılmış ve Cronbach's Alpha değerleri belirlenmiştir. Cronbach's Alpha değeri ölçek için 0,817 olarak ölçülürken, faktörler için ortaya çıkan değerler ise 0,528 ile 0,776 arasında değişmiştir. Özdamar (2002) ve Tavşancıl'a (2002) göre Cronbach's Alpha katsayısı, 0,40-0,59 arası düşük güvenilir, 0,60-0,79 arası oldukça güvenilir, $0,80-1,00$ arası ise yüksek derecede güvenilir olduğunu 
belirtmişlerdir. Dolayısıyla, deneyim arayışı faktörü düşük güvenilir, macera arayışı, sınırsızlık ve sıkıntı duyarlılığı oldukça güvenilir, genel ölçek ise yüksek derecede güvenilir olarak ölçülmüştür. Yapılan analize ilişkin faktörlerin öz değerleri, açıklanan varyansları, Cronbach's Alpha değerleri ve faktör yük değerleri Tablo 5'te gösterilmiştir.

Macera arayışı faktörü olan ilk faktör, varyansın yüzde 17,991'ini açıklamıştır. Bu faktörde toplam sekiz ifade yer almış ve faktör yük değerleri 0,484 ile 0,738 arasında değişmiştir. Macera arayışı faktörünün Cronbach's Alpha değeri ise 0,776 olarak hesaplanmıştır. Ölçeğin ikinci faktörü olan sıkıntı duyarlıığı faktörü, toplam yedi ifadeden oluşmakta olup, varyansın yüzde 10,294'ünü açıklamıştır. Cronbach's Alpha değeri 0,697 olarak ölçülen sıkıntı duyarlıığı faktörünün faktör yük değerleri ise 0,497 ile 0,679 değerleri arasında değişmiştir. Üçüncü faktör olan sınırsızlık faktörü, toplam beş ifadeden oluşmuş ve varyansın yüzde 8,340'ını açıklamıştır. Sınırsızlık faktörünün faktör yük değerleri 0,574 ile 0,728 arasında değişmiş, Cronbach's Alpha değeri ise 0,736 olarak ölçülmüştür. Deneyim arayışı olarak adlandırılan son faktörde, toplam dört ifade yer almış ve varyansın yüzde 5,889'unu açıklamıştır. Cronbach's Alpha değeri 0,528 olarak hesaplanan deneyim arayışı faktörünün faktör yük değerleri ise en düşük 0,447 , en yüksek 0,667 olarak ortaya çıkmıştır. Sonuç olarak, elde edilen dört faktörlü yapı, toplam varyansın yüzde 42,524'ünü açıklamıştır. Açıklanan varyansın yüksek olması, ilgili kavram ya da yapının o denli iyi ölçüldüğünün bir göstergesi olarak yorumlanır (Büyüköztürk, 2014). Çalışmada açıklanan varyansın 42,524 olarak ölçülmesi, örneklemin 10 farklı macera aktivitesine katılan örneklem grubundan oluşmasından kaynaklandığı sonucuna ulaşılabilir.

Tablo 5: Faktör analizi

\begin{tabular}{|c|c|c|c|c|c|c|}
\hline & & & & & $\frac{y}{5}$ & \\
\hline & Macera Arayışı & 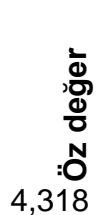 & 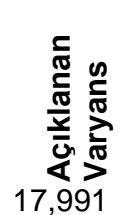 & 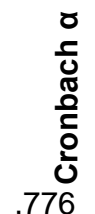 & 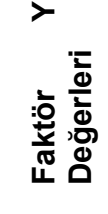 & 흠 \\
\hline RK & Rafting ve kano & & & &, 738 & 659 \\
\hline TD & Tüplü dalış & & & & ,712 & ,593 \\
\hline UP & Uçak, planör kullanmak & & & & ,684 & 660 \\
\hline SY & Sörf yapmak & & & & 677 & ,780 \\
\hline KS & Kayak/Snowboard & & & &, 545 &, 501 \\
\hline YP & Paraşüt atlayışı & & & &, 541 & 695 \\
\hline YG & Yelkenli & & & &, 509 & ,447 \\
\hline KT & Tırmanış yapmak & & & & ,484 & ,778 \\
\hline & Sıkıntı Duyarlılığı & 2,471 & 10,294 & ,697 & & \\
\hline AY & Aynı yüzler görmek & & & & 679 & ,469 \\
\hline $\mathrm{AF}$ & Filmi tekrar izlemek & & & & 609 & .599 \\
\hline DS & Sıkılmak & & & &, 599 & 413 \\
\hline $\mathrm{EH}$ & Evde huzursuz olmak & & & &, 593 &, 580 \\
\hline DS & Donuk ve sıkıcı bireyler & & & & .591 & 405 \\
\hline AŞ & Sürekli aynı şeyler yapmak & & & &, 527 &, 534 \\
\hline SBF & Sonu belli olan film izlemek & & & & ,497 &, 525 \\
\hline & Sınırsızlık & 2,002 & 8,340 & ,736 & & \\
\hline $\begin{array}{l}\text { HD } \\
\text { PARTi }\end{array}$ & Heyecan verici deneyimler & & & & $\begin{array}{l}, 728 \\
720\end{array}$ & ,692 \\
\hline
\end{tabular}


Tablo 5'in Devamı

\begin{tabular}{|c|c|c|c|c|c|c|}
\hline $\begin{array}{l}\text { FLÖRT } \\
\text { IÇKI } \\
\text { HiPPI }\end{array}$ & $\begin{array}{l}\text { Flört etmek } \\
\text { İcki } \\
\text { Hippiler ile arkadaşlık }\end{array}$ & & & & $\begin{array}{l}.670 \\
, 644 \\
, 574\end{array}$ & $\begin{array}{l}, 780 \\
, 551 \\
, 519\end{array}$ \\
\hline & Deneyim Arayışı & 1,416 & 5,899 & ,528 & & \\
\hline $\begin{array}{l}\text { YD } \\
\text { YI } \\
\text { GIY } \\
\text { ROTA }\end{array}$ & $\begin{array}{l}\text { Yeni deneyimler } \\
\text { Yiyecekler } \\
\text { Giyim } \\
\text { Rotasız geziye çıkmak }\end{array}$ & & & & $\begin{array}{l}, 667 \\
, 616 \\
, 461 \\
, 447\end{array}$ & $\begin{array}{l}, 412 \\
, 581 \\
, 500 \\
, 746\end{array}$ \\
\hline ROTA & Açıklanan Varyans Toplamı & & 42,524 & & & \\
\hline
\end{tabular}

\subsection{Hipotez Testleri}

H1: Macera turistlerinin duyusal arayışları, aktivite türlerine göre istatistiki olarak anlamlı farklılıklar göstermektedir.

Macera turistlerinin duyusal arayışlarının katıldıkları aktivite türlerine göre istatistiki olarak anlamlı farklılık gösterip göstermediğini ortaya koymak için tek yönlü ANOVA yapılmıştır. Analiz sonuçlarından çıkan anlamlı farklılıkların hangi gruplar arasında ortaya çıktığının incelenmesi için, Post-Hoc testlerden biri olan Tukey testi yapılmıştır. Tukey testi, grup sayısının fazla olduğu durumlarda kullanıldığı için tercih edilmiştir (Sipahi vd., 2008). Analiz Sonuçlarına göre, macera turistlerinin macera arayışı, sıkıntı duyarlılığı, sınırsızlık duygusu ve deneyim arayışı, aktivite türlerine göre istatistiki olarak anlamlı farklılıklar gösterdiği tespit edilmiştir $(p=, 000)$.

Tablo 6: Duyusal arayışın macera aktivite türlerine göre farklılaşması

\begin{tabular}{|c|c|c|c|c|}
\hline & Aktiviteler & Ort & SS & $P$ \\
\hline & Bisiklet & 3,89 & ,765 & \\
\hline & Kamp & 3,93 & ,840 & \\
\hline & Kano & 4,03 & ,776 & \\
\hline & Yamaç Paraşütü & 4,41 & ,258 & \\
\hline Macera & Kaya Tırmanışı & 4,25 &, 500 & \\
\hline Arayışı & Sörf & 4,18 &, 578 & ,000 \\
\hline & Dalış & 4,07 & ,727 & \\
\hline & Kayak/Snowboard & 4,08 & 613 & \\
\hline & Trekking & 3,88 & ,802 & \\
\hline & Rafting & 4,17 &, 547 & \\
\hline & Bisiklet & 3,04 & ,460 & \\
\hline & Kamp & 3,27 &, 537 & \\
\hline & Kano & 2,93 &, 575 & \\
\hline & Yamaç Paraşütü & 3,75 & ,228 & \\
\hline Sıkıntı & Kaya Tırmanışı & 3,39 & ,344 & \\
\hline & Sörf & 3,31 & ,418 &, $000^{* \star}$ \\
\hline & Dalış & 3,17 & ,474 & \\
\hline & Kayak/Snowboard & 3,38 & ,469 & \\
\hline & Trekking & 3,01 & ,451 & \\
\hline & Rafting & 3,46 & 377 & \\
\hline & Bisiklet & 3,62 & ,858 & \\
\hline & Kamp & 3,48 & 1,017 & \\
\hline Sınırsızlık & Kano & 3,72 & ,942 & ,000** \\
\hline & Yamaç Paraşütü & 3,95 & ,333 & \\
\hline
\end{tabular}


Tablo 6'nın Devamı

\begin{tabular}{|c|c|c|c|c|}
\hline $\begin{array}{l}\text { Deneyim } \\
\text { Arayışı }\end{array}$ & $\begin{array}{l}\text { Kaya Tırmanışı } \\
\text { Sörf } \\
\text { Dalış } \\
\text { Kayak/Snowboard } \\
\text { Trekking } \\
\text { Rafting } \\
\text { Bisiklet } \\
\text { Kamp } \\
\text { Kano } \\
\text { Yamaç Paraşütü } \\
\text { Kaya Tırmanışı } \\
\text { Sörf } \\
\text { Dalış } \\
\text { Kayak/Snowboard } \\
\text { Trekking } \\
\text { Rafting }\end{array}$ & $\begin{array}{l}4,34 \\
3,71 \\
3,64 \\
3,53 \\
3,55 \\
4,13 \\
4,06 \\
4,11 \\
3,72 \\
4,25 \\
4,38 \\
4,25 \\
4,29 \\
4,15 \\
3,98 \\
4,30\end{array}$ & \begin{tabular}{l|l|}
, 571 \\
, 743 \\
, 983 \\
, 924 \\
, 872 \\
, 605 \\
, 585 \\
, 622 \\
, 893 \\
, 353 \\
, 456 \\
, 454 \\
, 616 \\
, 726 \\
, 526 \\
, 537
\end{tabular} &, $000^{* *}$ \\
\hline
\end{tabular}

Analiz sonuçlarından elde edilen bu bulgulara göre (Tablo 6), yamaç paraşütü yapanların macera arayışı, tur bisikleti, kamp, kano, kayak, trekking ve tüplü dalış katılımcılarına göre daha yüksektir. Tur bisikleti ve kamp katılımcılarının kaya tırmanışı katılımcılarına göre, trekking katılımcılarının ise kaya tırmanışı, sörf ve rafting katılımcılarına göre macera arayışı daha düşüktür. Ayrıca, yamaç paraşütü yapanların, tur bisiklet, kamp, kano, kaya tırmanışı, sörf, kayak, trekking ve tüplü dalış katılımcılarına göre sıkıntı duyarlıığı daha yüksektir. Rafting yapanların, sıkıntı duyarlılığı tur bisikleti katılımcılarına göre daha yüksektir. Kano yapanların sıkıntı duyarlılığı, kamp, kaya tırmanışı, sörf, kayak ve rafting katılımcılarına göre, trekking yapanların sıkıntı duyarlıı̆̆ı ise rafting, kayak, sörf, kaya tırmanışı katılımcılarına daha düşüktür.

Kaya tırmanışı yapanların sınırsızık duygusu, yamaç paraşütü, sörf, bisiklet, kamp, kano, kayak, trekking ve tüplü dalış katılımcılarına göre daha yüksektir. Rafting yapanların ise sörf, tur bisiklet, kamp, kano, kayak, trekking ve tüplü dalış katılımcılarına göre sınırsızlık duygusu daha yüksektir. Yamaç paraşütü yapanların sınırsızlık duygusu ise tur bisikleti, kamp, kayak ve trekking katılımcılarına göre daha yüksektir. Son olarak, kano yapanların deneyim arayışı diğer tüm katılımcılara göre daha düşüktür. Ayrıca, trekking yapanların deneyim arayışı, kaya tırmanışı, yamaç paraşütü, sörf ve rafting katılımcılarına göre daha düşüktür. Tur bisikleti ve kamp katııımcılarının deneyim arayışı ise kaya tırmanışı katıımcılarına göre daha düşüktür.

ANOVA sonuçlarının değerlendirilmesi ile ulaşılan bulgular sonucunda, araştırmanın ilk hipotezi olan; "H1: Macera turistlerinin duyusal arayışları, aktivite türlerine göre istatistiki olarak anlamlı farklılıklar göstermektedir." hipotezi kabul edilmiştir.

\section{H2: Macera turistlerinin duyusal arayışları demografik özelliklere göre istatistiki olarak anlamlı farklılıklar göstermektedir.}

Macera turistlerinin duyusal arayışlarının demografik özelliklere göre istatistiki açıdan farklılaşma durumunu ortaya koymak amacıyla, cinsiyet, medeni durum ve milliyet değişkenleri için bağımsız örneklem t testi yapılırken, yaş, eğitim durumu, meslek ve gelir değişkenleri için ise tekyönlü ANOVA yapılmıştır. Sonuçlardan çıkan 
anlamlı farkların hangi gruplar arasında ortaya çıktığının incelenmesi için ise Post-Hoc testlerden biri olan Tukey testi yapılmıştır.

Tablo 7: Duyusal arayışın demografik özelliklere göre farklılaşması

\begin{tabular}{|c|c|c|c|c|c|c|c|}
\hline \multirow[b]{2}{*}{ Faktörler } & \multicolumn{7}{|c|}{ Demografik Özellikler } \\
\hline & $\begin{array}{l}\text { Cinsiyet } \\
(P)\end{array}$ & $\begin{array}{l}\text { Medeni } \\
\text { Durum } \\
\text { (P) }\end{array}$ & $\begin{array}{l}\text { Milliyet } \\
(P)\end{array}$ & $\begin{array}{l}\text { Yaş } \\
(P)\end{array}$ & $\begin{array}{l}\text { Eğitim } \\
\text { Durumu } \\
\text { (P) }\end{array}$ & $\begin{array}{l}\text { Meslek } \\
\text { (P) }\end{array}$ & $\begin{array}{l}\text { Gelir } \\
(P)\end{array}$ \\
\hline $\begin{array}{l}\text { Macera } \\
\text { Arayısı }\end{array}$ &, $000^{* *}$ & , 196 & ,959 & ,494 & ,782 &, $000^{* *}$ &, $027^{*}$ \\
\hline $\begin{array}{l}\text { Sıkıntı } \\
\text { Duyarııığı }\end{array}$ & ,065 &, $032^{*}$ &, $000^{* *}$ & ,494 &, $001^{* *}$ &, $004^{* *}$ &, $003^{* *}$ \\
\hline Sınırsızlık &, $001^{* *}$ &, $000^{* *}$ & ,080 &, $002^{* *}$ &, $006^{* *}$ &, $000^{* *}$ &, $013^{*}$ \\
\hline $\begin{array}{l}\text { Deneyim } \\
\text { Arayışı }\end{array}$ & ,492 & ,583 & ,344 & ,038* & ,261 & ,518 &, $000^{* *}$ \\
\hline
\end{tabular}

${ }^{* *} p<, 01{ }^{*} p<, 05$

Tablo 7 incelendiğinde, macera turistlerinin macera arayışı $(p=, 000)$ ve sınırsızlık duygusu $(p=, 001)$ cinsiyete göre anlamlı farklılıklar gösterdiği tespit edilmiştir. Buna göre, erkeklerin macera arayışı ve sınırsızlık duygusu kadınlara göre daha yüksektir. Ayrıca, bu turistlerin sıkıntı duyarlıığı $(p=, 032)$ ve sınırsızlık duygusu $(p=, 000)$ medeni duruma göre anlamlı farklılık göstermiştir. Buna göre, bekârların sınırsızlık duygusu evlilerden daha yüksekken, sıkıntı duyarlıığı ise daha düşüktür.

Macera turistlerinin sıkıntı duyarlıığı $(p=, 000)$ milliyetlerine göre anlamlı farklıııklar göstermiştir. Buna göre, yabancı turistlerin sıkıntı duyarlılığının yerli turistlere göre daha yüksek olduğu görülmüştür. Ayrıca, bu turistlerin deneyim arayışı $(p=, 038)$ ve sınırsızlık duygusu $(p=, 002)$ yaşa göre anlamlı farklılıklar göstermiştir. Bu iki faktörde hangi yaş gruplarına göre anlamlı farklılığın ortaya çıktığına yönelik ortaya çıkan analiz sonuçları, deneyim arayışı faktöründe yaşa göre anlamlı bir farkılık bulunmadığını göstermiştir. Sınırsızlık faktöründe ise 25-30 ve 31-40 yaş aralığındaki macera turistleri ile 56 ve üstü $(p<, 05)$ yaş grupları arasında anlamlı farklılık bulunmuştur. Şöyle ki 25-40 yaş aralığındaki macera turistlerinin sınırsızlık duygusu, 56 yaşın üstündekilere göre daha yüksektir.

Macera turistlerinin sıkıntı duyarlılığı $(p=, 001)$ ve sınırsızlık duygusu $(p=, 006)$ eğitim durumuna göre farklılaşmaktadır. Buna göre, lisans mezunlarının sıkıntı duyarlılığı, lisansüstü mezunlarına göre, sınırsızlık duygusu ise ilköğretim mezunlarına göre daha yüksektir. Ayrıca, bu turistlerin macera arayışı $(p=, 000)$, sıkıntı duyarlılığı $(p=, 004)$ ve sınırsızlık duygusu $(p=, 000)$ mesleklere göre anlamlı farklılıklar göstermiştir. Sonuç olarak, sporcular ve işsizlerin macera arayışı, öğrenciler ve kamu çalışanlarına göre daha yüksek çıkmıştır. Sporcuların sınırsızlık duygusu, işçiler ile kamu ve özel sektör çalışanlarına göre daha yüksekken, işçilerin sıkıntı duyarlılığı ise kamu ve özel sektör çalışanlarına göre daha yüksektir.

Macera turistlerinin macera arayışı, sıkıntı duyarlıı̆̆ı, sınırsızlık duygusu ve deneyim arayışının gelire göre anlamlı farklılıklar gösterdiği tespit edilmiştir $(p=, 000)$. Bu sonuçlara göre, 6000 TL ve üstü gelir grubunun macera arayışı, 3001-4000 TL gelir grubuna göre daha yüksektir. Ayrıca, 6000 TL üstü gelir grubunun sıkıntı duyarlıığı ve sınırsızlık duygusu 3001-4000 TL gelir grubuna göre daha yüksektir. Son olarak, 0- 
2000 TL gelir grubunun deneyim arayışı, 3001 TL ve üstü gelir gruplarına göre daha yüksektir.

Tek yönlü ANOVA ve t testi sonuçlarının değerlendirilmesi ile ulaşılan bulgular sonucunda; "H2: Macera turistlerinin duyusal arayışları demografik özelliklere göre istatistiki olarak anlamlı farkılıklar göstermektedir." hipotezi kısmen kabul edilmiştir.

\section{H3: Macera turistlerinin duyusal arayışları rekreasyonel davranış özelliklerine göre istatistiki olarak anlamlı farklııklar göstermektedir.}

Macera turistlerinin duyusal arayışlarının rekreasyonel davranış özelliklerine göre istatistiki olarak anlamlı farklılıklar gösterip göstermediğine yönelik, $t$ testi ve ANOVA yapılmıştır. Macera turistlerinin macera aktivitelerine tekrar katılma isteğini analiz etmek için bağımsız örneklem t testi kullanılırken; aktivite süresi, beceri düzeyi, yıllık ortalama harcama, aktivitelere katılım sıklığı ve aktivitelere zaman harcamanın analiz edilmesi için ise tekyönlü ANOVA yapılmıştır. Ayrıca, anlamlı farklılıkların hangi gruplar arasında ortaya çıktığının incelenmesi için ise Post-Hoc testlerden biri olan Tukey testi yapılmıştır.

Tablo 8: Duyusal arayışın rekreasyonel davranış özelliklere göre farklılaşması

\begin{tabular}{|c|c|c|c|c|c|c|}
\hline \multirow[b]{2}{*}{ Faktörler } & \multicolumn{5}{|c|}{ Rekreasyonel Davranış Özellikleri } & \multirow[b]{2}{*}{$\begin{array}{l}\text { Zaman } \\
\text { Harcama }(P)\end{array}$} \\
\hline & $\begin{array}{l}\text { Tekrar } \\
\text { Katılım } \\
(P)\end{array}$ & $\begin{array}{l}\text { Aktivite } \\
\text { Süresi } \\
(P)\end{array}$ & $\begin{array}{l}\text { Beceri } \\
\text { Düzeyi } \\
(P)\end{array}$ & $\begin{array}{l}\text { Yıllık } \\
\text { Harcama }(P)\end{array}$ & $\begin{array}{l}\text { Katılım } \\
\text { Sıklığı } \\
(P)\end{array}$ & \\
\hline $\begin{array}{l}\text { Macera } \\
\text { Arayışı }\end{array}$ &, $005^{\star *}$ &, $000^{\star \star}$ & ,068 &, $000^{* *}$ &, $000^{* *}$ &, $023^{*}$ \\
\hline $\begin{array}{l}\text { Sıkıntı } \\
\text { Duyarlılığı }\end{array}$ &, $008^{* *}$ &, $000^{\star \star}$ & ,476 &, $000^{* *}$ &, $000^{* *}$ &, $000^{\star \star}$ \\
\hline Sınırsızlık &, $047^{*}$ &, $000^{* *}$ &, $001^{\star \star}$ &, $000^{\star \star}$ &, $000^{* *}$ &, $004^{\star}$ \\
\hline $\begin{array}{l}\text { Deneyim } \\
\text { Arayışı }\end{array}$ & ,443 &, $000^{\star \star}$ &, $010^{\star \star}$ & ,049* &, $000^{* *}$ & ,667 \\
\hline
\end{tabular}

${ }^{* *} p<, 01{ }^{*} p<, 05$

Tablo 8 incelendiğinde, macera turistlerinin macera arayışı $(p=, 002)$, sıkıntı duyarlıığı $(p=, 008)$ ve sınırsızlık duygusu $(p=, 001)$ aktivitelere tekrar katılma niyetine göre anlamlı farklılıklar göstermiştir. Buna göre, aktivitelere tekrar katılmak isteyen macera turistlerinin, macera arayışı, sıkıntı duyarlıığı ve sınırsızlık duygusu katılmak istemeyenlere göre daha yüksektir. Ayrıca, macera turistlerinin macera arayışı, sıkıntı duyarııı̆̆ı, sınırsızlık duygusu ve deneyim arayışı, aktivite süresine göre anlamlı farklılıklar göstermiştir $(p=, 000)$. Elde edilen bulgular, bir yıldan daha az süredir macera aktivitelerine katılanların, macera arayışı, sınırsızlık duygusu ve deneyim arayışının daha düşük olduğuna işaret etmektedir. Ancak 8-10 yıldır bu aktivitelere katılanların sıkıntı duyarlıı̆̆ı, diğer gruplara göre daha yüksektir.

Macera turistlerinin sınırsızlık duygusu $(p=, 010)$ ve deneyim arayışı $(p=, 001)$, beceri düzeyine göre anlamlı farklılıklar göstermiştir. Buna göre, macera aktivitelerini profesyonel olarak yapanların sınırsızlık duygusu, amatör ve orta düzey öğrencilere göre daha yüksektir. Başlangıç seviyesindekilerin deneyim arayışı ise orta düzey öğrencilere göre daha yüksektir. Ayrıca, macera turistlerinin macera arayışı, sıkıntı duyarlıığı, sınırsızlık duygusu ve deneyim arayışı, yıllık harcamaya göre istatistiki olarak anlamlı farklılık göstermiştir $(p=, 000)$. Elde edilen bulgulara göre, macera 
aktivitelerine yıllık ortalama 0-500 TL arasında harcama yapanların macera arayışı, sıkıntı duyarlıı̆̆ı ve sınırsızlık duygusu, diğer harcama gruplarına göre daha düşüktür.

Macera turistlerinin macera arayışı, sıkıntı duyarlıı̆̆ı, sınırsızlık duygusu ve deneyim arayışı, katıım sıklığına göre anlamlı farklılıklar göstermiştir $(p=, 000)$. Elde edilen bulgulara göre, yılda bir defa macera aktivitelerine katılan macera turistlerinin macera arayışı ve sıkıntı duyarııı̆ı hem ayda bir defa hem de ayda iki ve daha çok katılanlara göre daha düşüktür. Ayrıca, ayda iki ve daha çok kez macera aktivitelerine katılanların sınırsızlık duygusu, yılda bir defa ve yılda 2-5 defa katılanlara göre daha yüksektir. Yılda bir defa macera aktivitelerine katılanların, deneyim arayışı, diğer tüm katılım gruplarına göre daha düşüktür. Son olarak, macera turistlerinin, macera arayışı $(p=, 023)$, sıkıntı duyarlılığı $(p=, 000)$ ve sınırsızlık duygusu $(p=, 004)$ aktivitelere harcanan zamana göre anlamlı farklılıklar göstermiştir. Buna göre, aktivitelere ortalama 8-10 saat zaman harcayanların sınırsızlık duygusu 2-4 saat ve 5-7 saat zaman harcayanlara göre daha yüksektir.

$\mathrm{Bu}$ açıklamalara bağlı olarak; "H3: Macera turistlerinin duyusal arayışları rekreasyonel davranış özelliklerine göre istatistiki olarak anlamlı farklılıklar göstermektedir." hipotezi kısmen kabul edilmiştir.

\subsection{Kümeleme Analizi: Macera Turistlerinin Uyarılma Düzeyleri}

Duyusal arayış ölçeği, macera turistlerinin duyusal arayışları ile birlikte, uyarılma düzeylerini de ölçmektedir. Ölçekte yer alan 30 ifadenin toplam puanları ve ortalamaları ile macera turistlerinin hangi düzeyde uyarıldıklarını ortaya konmuştur. Macera turistlerinin duyusal arayışlarına göre uyarılma düzeyleri belirlenerek, bu düzeyleri sınıflayabilmek için duyusal arayış ifadelerine, 1-5 arasında puanlar verilmiştir. Dolayısıyla, duyusal arayış ifadelerinden alınabilecek toplam değerler, 24120 puan arasında değişmektedir. Değer 120'ye yaklaştıkça, macera turistlerinin uyarılma düzeyi artmakta, 24'e yaklaştıkça uyarılma düzeyi azalmaktadır. Bu bağlamda, hiyerarşik olmayan kümeleme analizi sonucunda, macera turistlerinin uyarılma düzeyleri, düşük, orta ve yüksek düzey olarak ortaya çıkmıştır

Yapılan kümeleme analizi sonucunda, 0-78 puan arasında puana sahip macera turistleri düşük düzeyde uyarılanlar, 79-94 puana sahip macera turistleri orta düzeyde uyarılanlar, 95-120 puan aralığında yer alan macera turistleri ise yüksek düzeyde uyarılanlar olarak belirlenmiştir. Düşük düzeyde uyarılanların toplam puan ortalamaları 70,16 , orta düzeyde uyarılanların toplam puan ortalamaları 87,16 , yüksek düzeyde uyarılanların toplam puan ortalamaları ise 101,74 olarak ölçülmüştür.

Oluşan kümelerin sayıları ve yüzdeleri incelendiğinde, düşük düzeyde uyarılanların sayısı 162 (\%13), orta düzeyde uyarılanların sayısı 577 (\%46,30), yüksek düzeyde uyarılanların sayısı ise $507(\% 41,70)$ olarak ortaya çıkmıştır. Üç kümede sınıflanan macera turistlerinin aritmetik ortalamaları ise düşük düzeyde uyarılanlar için 2,94 , orta düzeyde uyarılanlar için 3,63 , yüksek düzeyde uyarılanlar için ise 4,23 olmuştur. Tablo 9 , her küme için aritmetik ortalamaları, standart sapmaları, minimum ve maksimum değerleri, yüzdeleri ve katılımcı sayılarını göstermektedir. 
Tablo 9: Uyarılma düzeyleri ile ilgili ortalamalar ve yüzdeler

\begin{tabular}{|lcccccc|}
\hline Uyarılma Düzeyleri & Ort & SS & Min & Maks & Sayı & Yüzde \\
Düşük Düzey & 2,94 &, 2918 & 2,04 & 3.25 & 162 & 13,00 \\
Orta Düzey & 3,63 &, 1922 & 3,29 & 3,92 & 577 & 46,30 \\
Yüksek Düzey & 4,23 &, 1883 & 3,96 & 4,96 & 507 & 41,70 \\
\hline
\end{tabular}

Macera turistlerinin aktivite türlerine göre uyarılma düzeyleri incelendiğinde (Tablo 10), yamaç paraşütü, kaya tırmanışı ve rafting aktivitelerine katılan macera turistleri çoğunlukla yüksek düzeyde uyarılanlar kümesinde yer almıştır. Bu üç aktivitenin tümünde, yüksek düzeyde uyarılanlardan sonra sayıca daha fazla olanlar, orta düzeyde uyarılanlar olmuştur. Tur bisikleti, kamp, kano, sörf, kayak/snowboard, trekking ve tüplü dalış aktivitelerine katılanlar ise daha çok orta düzeyde uyarılanlar kümesinde yer almışlardır.

Tablo 10: Macera aktivite türleri için uyarılma düzeylerinin karşılaştırılması

\begin{tabular}{|lccccc|}
\hline Uyarılma Düzeyleri & Bisiklet & Kamp & Kano & Y.Paraşütü & K.Tırmanışı \\
Düşük Düzey & 24 & 32 & 26 & - & - \\
Orta Düzey & 73 & 50 & 54 & 34 & 48 \\
Yüksek Düzey & 32 & 48 & 32 & 90 & 69 \\
\hline \hline Uyarılma Düzeyleri & Sörf & Kayak/S & Rafting & Trekking & T.Dalış \\
Düşük Düzey & 13 & 17 & 5 & 32 & 13 \\
Orta Düzey & 63 & 63 & 45 & 90 & 57 \\
Yüksek Düzey & 49 & 49 & 58 & 34 & 46 \\
\hline
\end{tabular}

\section{Tartışma, Sonuç ve Öneriler}

Araştırma, Türkiye'de en çok tercih edilen macera aktiviteleri olan; yamaç paraşütü, kaya tırmanışı, rafting, sörf, tüplü dalış, kayak/snowboard, kano, kamp, trekking ve tur bisikleti aktivitelerine katılan 1246 macera turisti kapsamında gerçekleştirilmiştir. Araştırma kapsamında ulaşılan sonuçlara göre macera turistlerinin ağılıklı olarak, Pizam (2004), Tanrısevdi (2009), Ewert vd. (2013), Gilbertson ve Ewert (2015), Arslan Ayazlar (2015) ve Jin vd., (2019)'nin araştırmalarını destekler nitelikte eğitimli bekâr gençlerden oluşmaktadır. Ayrıca, macera turistleri ortalama bir gelire sahip, yerli ve amatördür. Araştırmada ortaya çıkan macera turistlerinin demografik özellikleri ile rekreasyonel davranış özellikleri ise Hsieh (2007)'in Tayvan'da, Giddy ve Webb (2016)'in Tsitsikamma'da (Güney Afrika), Caber ve Albayrak (2016)'ın Antalya'da yapmış oldukları araştırmalar ile uyumluluk göstermektedir. Ancak bu çalışmanın sonuçları Akgündüz ve Kızılcalıoğlu (2016)'nun trekking katılımcılarına yönelik yaptıkları araştırma ile yaş ve medeni durum bakımından farklılık göstermektedir. Dolayısıyla, macera turistlerine yönelik aktivitelerin planlamasında ve pazarlanmasında tüm elde edilen bu sonuçlara göre hareket edilmesinde fayda vardır.

Araştırmada, macera arayışı ve deneyim arayışının macera turistlerinin riskli aktiviteleri seçmelerindeki en önemli duyusal arayış faktörleri olduğu saptanmıştır. Gilbertson ve Ewert (2015) ile Park ve Stangl (2020) da benzer şekilde macera turistlerinin daha çok deneyim ve macera arayışı için seyahat ettiklerini belirtmişlerdir. Dolayısıyla, macera ve deneyim yaşamak isteyen macera turistlerinin yüksek risk içeren macera aktivitelerine katılmaları doğal bir sonuçtur. Bu turistlerin macera aktiviteleri tercihleri bağlamında değerlendirildiğinde ise yamaç paraşütü ve kaya tırmanışına katılanlar hem deneyim ve macera arayışı hem de genel duyusal arayış için en yüksek puanlara sahiplerdir. Ulaşılan bu sonuçlar, Trimpop vd., (1999)'nin 
paraşüt ve dağcılık katılımcılarına, Hsieh (2007)'in yamaç paraşütü katılımcılarına, Gilbertson ve Ewert (2015)'in ise kaya tırmanışı katılımcılarına yönelik sonuçları ile örtüşmektedir. Dolayısıyla, duyusal arayışın macera turizminin ayrılmaz bir parçası olduğu ve yüksek riskli aktivite katılımcılarının duyusal arayışlarının daha yüksek olduğu, Lepp ve Gibson (2003/2008) ile Malkin ve Rabinowitz (1998) araştırmalarını da desteklemektedir. Ayrıca, Wagner ve Houlihan (1994), planör aktivitesine katılanların duyusal arayışının golfçülere göre daha yüksek olduğunu belirtmişlerdir. Aynı şekilde Pizam vd. (2004), macera aktivitelerine katılan turistlerin duyusal arayışının, sıradan turizm faaliyetlerine katılanlara göre daha yüksek olduğu sonucuna ulaşmışlardır. Rainey vd. (1992) ve Zuckerman (1983) ise macera aktivitelerinde risk düzeyi yükseldikçe, turistlerin duyusal arayışlarının da arttığını belirtmişlerdir. Buraya kadarki tartışmalara ve araştırmada elde edilen sonuçlara dayanarak, macera aktivitelerindeki risk düzeyi arttıkça katılımcıların duyusal arayışlarının artıı̆ı sonucuna varılmıştır. Ayrıca, yamaç paraşütü ve kaya tırmanışının, macera aktiviteleri arasında en yüksek risk taşıyan aktiviteler olarak görüldüğü söylenebilir. Bu nedenle, bu aktivitelerin risk düzeylerine göre sınıflandırılarak, macera turistlerinin hizmetine sunulması, macera aktiviteleri destinasyonları için önem arz etmektedir.

Araştırma kapsamındaki dikkat çekici bir başka sonuç, macera turistlerinin uyarılma düzeylerinin düşük, orta ve yüksek düzey olarak farklılaşabilmesi yönündedir. Bu sonuç, Leuba (1955)'nın, bireylerin genel uyarılma düzeylerinin düşük, orta ve yüksek olduğu durumlarda farklı reaksiyonlar verme eğiliminde olduklarını savunduğu görüşünü desteklemektedir. Araştırmada, macera turistlerinin hangi düzeyde uyarıldıklarına yönelik ulaşılan sonuçlar, bu turistlerin daha çok orta ve yüksek düzeyde uyarılanlar kümesinde yer aldıklarını göstermektedir. Buna göre optimal düzeyde uyarılmak için seyahat eden macera turistlerinin, daha çok orta ve yüksek düzeylerde hedefledikleri uyarılma düzeylerine ulaştıkları söylenebilir. Dolayısıyla, istedikleri uyarılma düzeylerine ulaşmalarına olanak sağlayacak riskli macera aktiviteleri sunan destinasyon sayısının artması gerekmektedir.

Macera turistlerinin aktivite tercihlerine göre değerlendirildiğinde ise yamaç paraşütü, kaya tırmanışı ve rafting aktivitelerine katılan macera turistleri daha çok yüksek düzeyde uyarılanlar kümesinde yer almıştır. Tur bisikleti, kamp, kano, sörf, kayak/snowboard, trekking ve tüplü dalış aktivitelerine katılanlar ise daha çok orta düzeyde uyarılanlar kümesinde yer almışlardır. Aktivitelerin tamamında en az katılımcı sayısına sahip olan küme, düşük düzeyde uyarılanlar kümesi olmuştur. Özellikle, yamaç paraşütü ve kaya tırmanışı aktivitelerine katılanlardan düşük düzeyde uyarılanlar kümesine mensup hiçbir katılımcı olmaması, bu aktivitelere katılan macera turistlerinin daha çok risk almak istedikleri fikrini desteklemektedir. Dolayısıyla, macera aktivitelerinin barındırdıkları risk unsurlarına göre sınıflandırılması, destinasyonun macera turistlerini doğru anlayabilmesi için önemlidir.

Sonuç olarak, macera turistlerinin tercih ettikleri 10 aktivite bağlamında, duyusal arayışları, uyarılma düzeyleri ile demografik ve rekreasyonel davranış özelliklerine göre farklılık gösterdiği belirlenmiştir. Duyusal arayışı yüksek olan macera turistleri, seyahat düzenlemelerini bağımsız olarak yapmayı, alışılmadık veya nadir tercih edilen destinasyonları ziyaret etmeyi ve riskli macera aktivitelerine katılmayı tercih etmesi beklenmektedir. Öte yandan, duyusal arayışı düşük olan macera turistleri, gruplar halinde seyahat etmeyi, bilindik destinasyonları ziyaret etmeyi ve daha az riskli rekreasyonel aktivitelere katılmayı tercih etme intimalleri daha yüksektir. Bu nedenle, macera destinasyonu olma yolunda girişimde bulunan destinasyonların kendilerini konumlandırmaları, bu kümeler özelinde değerlendirilmelidir. 
Gelecekte bu bağlamda yapılması planlanan çalışmalarda ise Türkiye'nin farklı bölgelerinde ön plana çıkmış veya çıkması muhtemel diğer macera aktivitelerine odaklanabilir. Ayrıca, spesifik olarak seçilmiş bir macera aktivitesi için Türkiye'deki tüm destinasyonları kapsayıcı çalışmalar yapılabilir. Destinasyonların macera turistleri için hangi farklı macera aktivitelerini sunulabileceğine yönelik çalışmalar yapılabilir. Yüksek riskli aktiviteler sunarak, macera turistlerine yeni deneyim alanları yaratmak, destinasyonlar için olmazsa olmazdır. Sunulan macera aktivitelerinin macera turistleri ile doğal çevre arasında bir denge sağlaması ve çevrenin zarar görmemesi önceliklerden biri olmalıdır. Macera aktiviteleri tehlike arz ettiğinden yaralanma ve ölüm riski mevcuttur. Destinasyonlar aktivitelere bağlı olarak güvenlik düzenlemeleri yapabilir ve acil müdahale alanları oluşturulabilir. Macera turistlerinin deneyim ve bilgi durumlarını belgeleyebilecekleri sertifikalar istenebilir ve sertifika sahibi olmayanlar için ek önlemler alınabilir. Seyahat acentelerinin macera turizmindeki etkinliği artırılabilir. Ancak aktivitelerin yapıldığı alanlarda, alan kılavuzları ve acente yetkililerinin aktiviteler hakkındaki teknik bilgilerinin yeterli olması önemlidir.

\section{Kaynakça}

Adventure Travel Trade Association (2018). Adventure Tourism Development İndex. The 2018 Report. http://www.adventuretravel.biz (Erişim Tarihi:02.09.2019).

Akgündüz, Y. ve Kızılcalığlu, G. (2016). Likya Yolu'nu Yürüyen Turistlerin Seyahat Motivasyonları ve Memnuniyet Düzeyleri. Journal of Management \& Economics, 23(3), ss. 817-836

Akoğlan Kozak, M. ve Bahçe, S. (2016). Özel Ilıgi Turizmi. Ankara: Detay Yayıncılık.

Apter, M. J. (1976). Some Data Inconsistent with the Optimal Arousal Theory of Motivation. Perceptual and Motor Skills, 43(3), ss. 1209-1210.

Arslan Ayazlar, R. (2015). Akış Deneyiminin Yamaç Paraşütü Deneyim Doyumu ve Yaşam Doyumuna Etkileri. Yayımlanmamış Doktora Tezi, Adnan Menderes Üniversitesi, Sosyal Bilimler Enstitüsü, Aydın.

Berlyne, D. E. (1960). Conflict, Arousal and Curiosity. New York: McGraw-Hill.

Buckley, R. (2012). Rush as a Key Motivation in Skilled Adventure Tourism: Resolving the Risk Recreation Paradox. Tourism Management, 33(4), ss. 961-970.

Büyüköztürk, Ş., Çakmak, E., Akgün, Ö., Karadeniz, Ş. ve Demirel, F. (2014). Bilimsel Araştırma Yöntemleri. Ankara: Pegem Yayınevi.

Caber, M. ve Albayrak, T. (2016). Push or Pull? Identifying Rock Climbing Tourists' Motivations. Toursim Management, 55, ss. 74-84.

Chen, S. L., Ou, S. J. ve Lin, L. Z. (2001). Application in Recreation and Leisure. Taipei City: Shin Hsin University.

Creswell, J. W. (2013). Araştırma Deseni: Nicel, Nitel ve Karma Yöntem Yaklaşımları. (S. Demir, Çev). Nebraska-ABD: SAGE Publications.

Csikszentmihalyi, M. (1990). Flow: The Psychology of Optimal Experience. New York: Harper Perennial.

Cüceloğlu, D. (2018). Insan ve Davranışı-Psikolojinin Temel Kavramları (36. Basım). İstanbul: Remzi Kitabevi.

Ewert, A. W. ve Hollenhurst, S. (1989). Testing the Adventure Model: Empirical Support for a Model of Risk Recreation Participation. Journal of Leisure Research, 21, ss. 124-139.

Ewert, A. W. ve Hollenhorst, S. (1997). Adventure Recreation and Its Implication for Wildness. International Journal of Wilderness, 3(2), ss. 21-26.

Ewert, A. W., Gilbertson, K., Luo, Y. C. ve Voight, A. (2013). Beyond "Because It's There": Motivations for Pursuing Adventure Recreational Activities. Journal of Leisure Research, 45(1), ss. 91-111. 
Eysenck, H. ve Eysenck, S. (1970). The Eysenck Personality Inventory. San Diego: Edits.

Fiske, D. W. ve Maddi, S. R. (1961). Functions of Varied Experience. Homewood, III.: Dorsey Press.

Giddy J. K. ve Webb N. L. (2016). The Influence of the Environment on Motivations to Participate in Adventure Tourism: The case of the Tsitsikamma. South African Geographical Journal. 98(2), ss. 351-366.

Gilberston, K. ve Ewert, A. (2015). Stability of Motivations and Risk Attractiveness: The Adventure Recreation Experience. Risk Management, 17(4), ss. 276-297.

Hair, J., Anderson, R., Tatham, R. ve Black, W. (2005). Multivariate Data Analysis. NJ: Prentice-Hall.

Hsieh, T. C. (2007). Recreational Motivation, Sensation Seeking, and Recreational Involvement of Taiwan's Adventure Recreation Participants. Yayınlanmamış Doktora Tezi, University of the Incarnate Word, San Antonio

Hebb, D. O. (1955). Drives and the CNS (Conceptual Nervous System). Psychological Review, 62(4), ss. 243.

II Turizm Müdürlükleri, (2019). http://www.kultur.gov.tr/TR-96683/il-kultur-turizmmudurlukleri-internet-siteleri.html. (Erişim Tarihi:10.02.2019.)

Jackson, M., White, G. ve White, M. (2001). Developing a Tourist Personality Typology. Proceedings of National Research Conference, Australia, ss. 177184.

Jin, X., Xiang, Y., Weber, K. ve Liu, Y. (2019). Motivation and Involvement in Adventure Tourism Activities: A Chinese Tourists' Perspective. Asia Pacific Journal of Tourism Research, 24(11), ss. 1066-1078.

Kültür ve Turizm Bakanlığı. (2019). http://yigm.kulturturizm.gov.tr (Erişim Tarihi:24.10.2019)

Lepp, A. ve Gibson, H. (2003). Tourist Roles, Perceived Risk, and International Tourism. Annals of Tourism Research, 30, ss. 606-624.

Lepp, A. ve Gibson, H. (2008). Sensation Seeking and Tourism: Tourist Role, Perception of Risk and Destination Choice. Tourism Management, 29, ss. 740750

Leuba, C. (1955). Toward Some Integration of Learning Theories: The Concept of Optimal Stimulation. Psychological Reports, 1(1), ss. 27-33.

Lipscombe, N. (1999). The Relevance of The Peak Experience to Continued Skydiving Participation: A Qualitative Approach to Assessing Motivations. Leisure Studies, 18, ss. 267-288.

Litvin, S. (2008). Sensation Seeking and Its Measurement for Tourism Research. Journal of Travel Research, 46(4), ss. 440-445.

Lynch, P. ve Dibben, M. (2016). Exploring Motivations for Adventure Recreation Events: A New Zealand Study. Annals of Leisure Research, 19(1), ss. 80-97.

Malkin, M. J. ve Rabinowitz, E. (1998). Sensation Seeking and High-Risk Recreation. Parks \& Recreation. 33(7), ss. 34-39.

Mason, M., Gos, L. and Moretti, A. (2017). Motivations, perceived risk and behavioural intentions in hard adventure tourism. A natural park case study. Sinergie Italian Journal of Management, 34, 181-199

Murray, D. M. (2003). Living on the Edge: Sensation Seeking and Extreme Sports Participation. Yayınlanmamış Doktora Tezi, University of Connecticut, Connecticut.

Özdamar, K. (2002). Paket Programlar ile İstatistik Veri Analizi. Eskişehir: Kaan Kitapevi.

Park, S. ve Stangl, B. (2020). Augmented Reality Experiences and Sensation Seeking. Tourism Management, 77, ss. 104023. 
Pizam, A., Jeong, G. H., Reichel, A., van Boemmel, H., Lusson, J. M., Steynberg, L. Mason, M. ve Montmany, N. (2004). The Relationship Between Risk-Taking, Sensation-Seeking, and the Tourist Behavior of Young Adults: A Cross-Cultural Study. Journal of Travel Research, 42(3), ss. 251-260.

Plog, S. (1987). Understanding Psychographics in Tourism Research. Travel, Tourism and Hospitality Research. New York: Wiley.

Pomfret, G. (2006). Mountaineering Adventure Tourists: A Conceptual Framework for Research. Tourism Management, 27(1), ss. 113-123.

Rainey, D. W., Amunategui, F., Agocs, H. veLarick, J. (1992). Sensation Seeking and Competitive Trait Anxiety Among College Rodeo Athletes. Journal of Sport Behavior, 15(4), ss. 307.

Sipahi, B., Yutrkoru, E. S. ve Çinko, M. (2008). Sosyal Bilimlerde SPSS'le Veri analizi. İstanbul: Beta Yayınları.

Sung, H. H. (2004). Classification of Adventure Travelers: Behavior, Decision Making, and Target Markets. Journal of Travel Research, 42(4), ss. 343-356.

Swarbrooke, J., Beard, S, C., Leckie, S. ve Pomfret, G. (2003) Adventure Tourism: The New Frontier. Oxford: Butterworth Heinemann.

Wagner, A. M. ve Houlihan, D. D. (1994). Sensation seeking and trait anxiety in hangglider pilots and golfers. Personality and Individual Differences. 16(6), 975-977.

Warburton, N. (2015). Felsefenin Kısa Tarihi. (G. Ateşoğlu, Çev.) İstanbul: Alfa Felsefe.

Weber, K. (2001). Outdoor Adventure Tourism: A Review of Research Approaches. Annals of Tourism Research, 28(2), ss. 360-377.

World Tourism Organization, (2019). UNWTO World Tourism Barometer and Statistical Annex. UNWTO, Madrid.

Tanrısevdi, A. (2009). Türk Özel İlgi Gezginleri Sansasyon Arama Özelliği Sergilemekte Midir? Ege Academic Review, 9(4), ss. 1313-1340.

Tavşancıl, E. (2006). Tutumların Ölçülmesi ve SPSS ile Veri Analizi. Ankara: Nobel Yayın Dağıtım.

Trimpop, R., Kerr, J. ve Kirkcaldy, B. (1999). Comparing Personality Constructs of Risk-Taking Behavior. Personality and Individual Differences, 26, ss. 237-254.

Zuckerman, M., Eysenck, S. B. ve Eysenck, H. J. (1978). Sensation Seeking in England and America: Cross-Cultural, Age, and Sex Comparisons. Journal of Consulting and Clinical Psychology, 46(1), ss. 139.

Zuckerman, M. (1979). Sensation Seeking (Psychology Revivals): Beyond the Optimal Level of Arousal. Psychology Press.

Zuckerman, M. (1983). Sensation Seeking and Sports. Personality and Individual Differences, 4(3), ss. 285-292.

Zuckerman, M. (1994). Behavioral Expressions and Biosocial Bases of Sensation Seeking. Cambridge University Press.

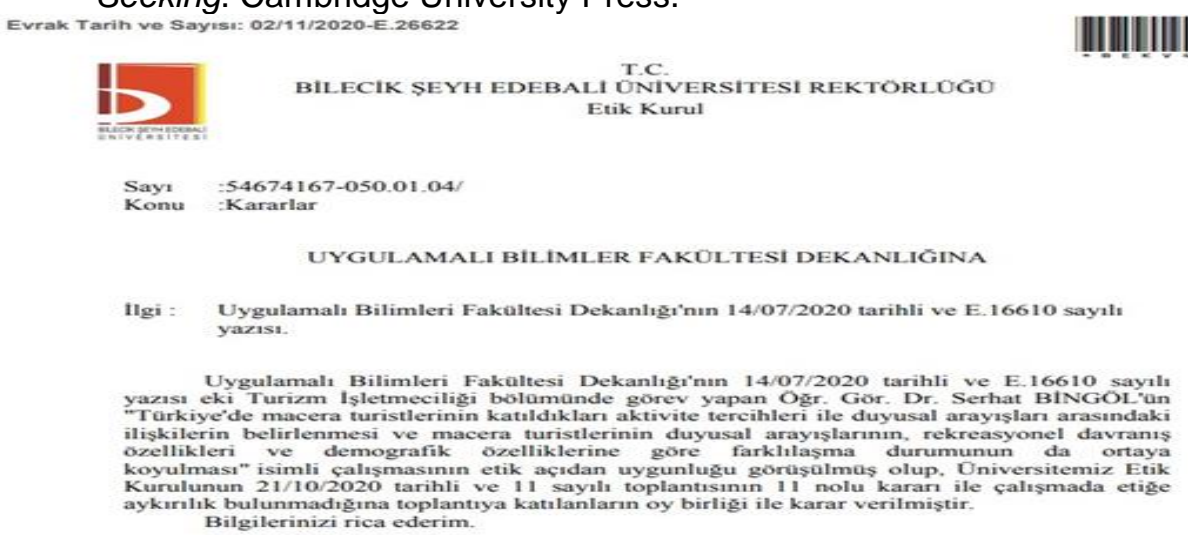

